\title{
Lipid Signaling in T-Cell Development and Function
}

\author{
Yina H. Huang ${ }^{1}$ and Karsten Sauer ${ }^{2}$ \\ ${ }^{1}$ Department of Pathology, Washington University School of Medicine, St. Louis, Missouri 63110 \\ ${ }^{2}$ Department of Immunology and Microbial Science, The Scripps Research Institute, La Jolla, \\ California 92037 \\ Correspondence: ksauer@scripps.edu
}

\begin{abstract}
Second messenger molecules relay, amplify, and diversify cell surface receptor signals. Two important examples are phosphorylated D-myo-inositol derivatives, such as phosphoinositide lipids within cellular membranes, and soluble inositol phosphates. Here, we review how phosphoinositide metabolism generates multiple second messengers with important roles in T-cell development and function. They include soluble inositol $(1,4,5)$ trisphosphate, long known for its $\mathrm{Ca}^{2+}$-mobilizing function, and phosphatidylinositol $(3,4,5)$ trisphosphate, whose generation by phosphoinositide 3-kinase and turnover by the phosphatases PTEN and SHIP control a key "hub" of TCR signaling. More recent studies unveiled important second messenger functions for diacylglycerol, phosphatidic acid, and soluble inositol $(1,3,4,5)$ tetrakisphosphate $\left(\mathrm{IP}_{4}\right)$ in immune cells. Inositol $(1,3,4,5)$ tetrakisphosphate acts as a soluble phosphatidylinositol $(3,4,5)$ trisphosphate analog to control protein membrane recruitment. We propose that phosphoinositide lipids and soluble inositol phosphates (IPs) can act as complementary partners whose interplay could have broadly important roles in cellular signaling.
\end{abstract}

Second messenger molecules relay, amplify, and diversify signals perceived by cell surface receptors. One important second messenger family is comprised of the phosphorylated derivatives of the small cyclic poly-alcohol Dmyo-inositol. They include phosphoinositide lipids within cellular membranes, and soluble inositol phosphates, here termed IPs. In most stimulatory cells, the plasma membrane phosphoinositide, phosphatidylinositol(4,5)bisphosphate (here termed $\mathrm{PIP}_{2}$ for improved readability, although several different $\mathrm{PIP}_{2}$ isomers exist) is a key precursor for both other phosphoinositides and soluble IPs. Many of these regulate distinct and overlapping downstream effectors (Irvine and Schell 2001; Alcazar-Roman and Wente 2008; Resnick and Saiardi 2008; Sauer et al. 2009; Shears 2009; Sauer and Cooke 2010). In particular, class I phosphoinositide 3-kinases (PI3K) phosphorylate $\mathrm{PIP}_{2}$ at the 3-position of its inositol-ring into phosphatidylinositol $(3,4,5)$ trisphosphate (here termed PIP $_{3}$ ) (Fig. 1) after receptor stimulation (Vanhaesebroeck et al. 2005; Juntilla and Koretzky 2008; Buitenhuis and Coffer 2009; Fruman and Bismuth 2009). Receptor-induced

Editors: Lawrence E. Samelson and Andrey Shaw

Additional Perspectives on Immunoreceptor Signaling available at www.cshperspectives.org

Copyright (C) 2010 Cold Spring Harbor Laboratory Press; all rights reserved; doi: 10.1101/cshperspect.a002428

Cite this article as Cold Spring Harb Perspect Biol 2010;2:a002428 
Y.H. Huang and K. Sauer

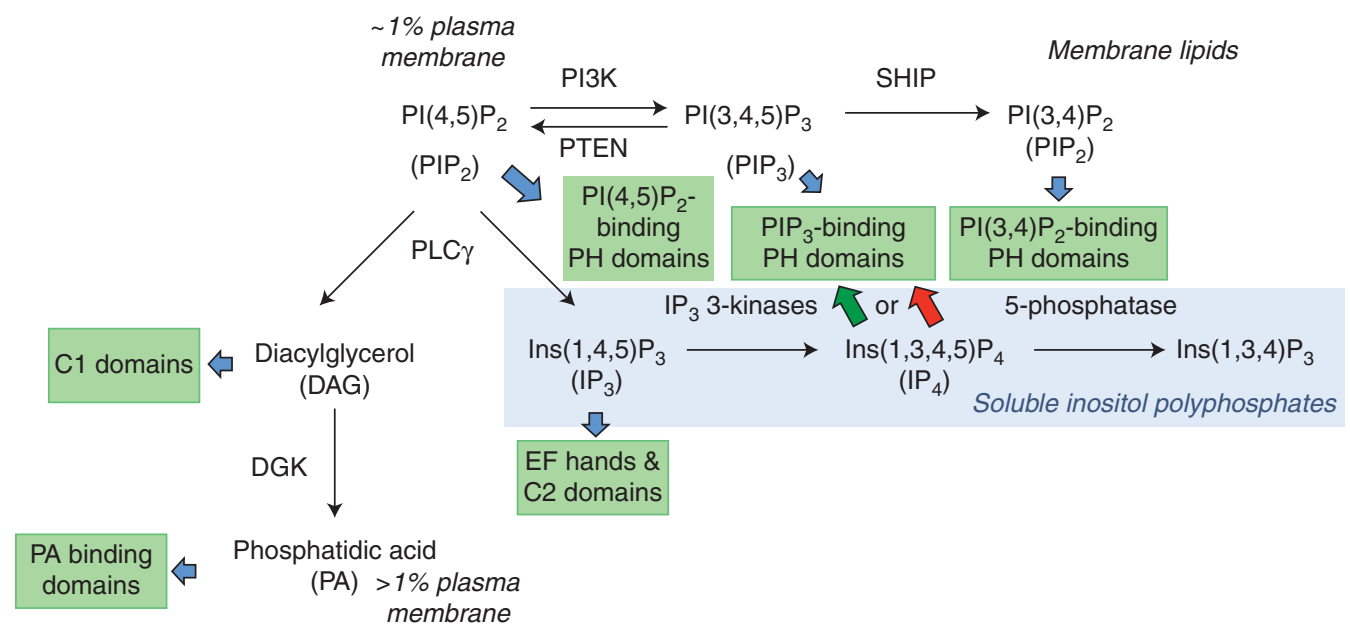

Figure 1. The phosphoinositide $\mathrm{PI}(4,5) \mathrm{P}_{2}$ is a key node of second messenger metabolism in lymphocytes. $\mathrm{PI}(4,5) \mathrm{P}_{2}$-phosphorylation by PI3-kinases and $\mathrm{PI}(4,5) \mathrm{P}_{2}$-hydrolysis by PLC $\gamma$ initiate several second messenger cascades within cellular membranes and soluble compartments. These second messengers can have various functions, including the recruitment and/or activation of effector proteins by binding to specific domains within them (blue arrows and green boxes). In particular, the phosphatases SHIP1/2 or PTEN limit or downregulate $\mathrm{PIP}_{3}$ levels and the functions of $\mathrm{PIP}_{3}$ and its effectors by hydrolyzing $\mathrm{PIP}_{3}$ into $\mathrm{PI}(3,4) \mathrm{P}_{2}$ or $\mathrm{PI}(4,5) \mathrm{P}_{2}$, respectively. For group $1 \mathrm{D}, \mathrm{PH}$ domains such as that of Akt, $\mathrm{PI}(3,4) \mathrm{P}_{2}$ binding sustains effector activity (Cozier et al. 2004; DiNitto and Lambright 2006; Lemmon 2008). PI(4,5) $\mathrm{P}_{2}$ recruits proteins such as RASA3/GAP $1{ }^{\mathrm{IP} 4 \mathrm{BP}}$ by binding to their PH domains (Lockyer et al. 1997; Cozier et al. 2000a; Cozier et al. 2000b). Hence, both PIP $_{2} \mathrm{~S}$ and $\mathrm{PIP}_{3}$ can have partially overlapping functions depending on the lipid-binding protein domain involved. PLC $\gamma$ hydrolyzes PI $(4,5) \mathrm{P}_{2}$ into protein $\mathrm{C} 1$ domain binding DAG and into $\mathrm{IP}_{3}$, which binds $\mathrm{EF}$ and $\mathrm{C} 2$ domain containing proteins and mobilizes $\mathrm{Ca}^{2+}$. IP 3 3-kinases convert $\mathrm{IP}_{3}$ into $\mathrm{IP}_{4}$, which acts as a soluble $\mathrm{PIP}_{3}$ analog and controls the abilities of certain $\mathrm{PH}$ domains to bind to $\mathrm{PIP}_{3}$ either positively (green arrow) or negatively (red arrow). An unknown 5-phosphatase metabolizes $\mathrm{IP}_{4}$ into $\mathrm{I}(1,3,4) \mathrm{P}_{3}$, a precursor for higher-order IPs. In vitro, SHIP1 and PTEN can dephosphorylate $\mathrm{IP}_{4}$ at the 5- or 3-positions, respectively (Erneux et al. 1998; Maehama and Dixon 1998; Pesesse et al. 1998; Caffrey et al. 2001). Whether this occurs physiologically is unknown. Finally, DAG kinases (DGKs) down-regulate DAG function by phosphorylating it into PA, itself a ligand for certain proteins. Further metabolism of all these second messengers results in the generation of many lipid and soluble metabolites. Several of these have important signaling functions (Irvine 2001; Irvine and Schell 2001; York and Hunter 2004; York 2006; Alcazar-Roman and Wente 2008; Huang et al. 2008; Jia et al. 2008b; Miller et al. 2008; Burton et al. 2009; Shears 2009; Sauer and Cooke 2010; Schell 2010). Their functions in immunocytes are unknown.

$\mathrm{PIP}_{2}$-hydrolysis by phospholipases such as PLC $1 / 2$ in lymphocytes generates the lipid diacylglycerol (DAG) and the soluble IP inositol $(1,4,5)$ trisphosphate $\left(\mathrm{IP}_{3}\right) . \mathrm{PIP}_{3}, \mathrm{DAG}$, and $\mathrm{IP}_{3}$ have essential second messenger functions in many cells, including lymphocytes. Here, we review the importance of phosphoinositide signaling in $\mathrm{T}$ cells and highlight the importance of a recently identified, intriguing molecular interplay between second messenger lipids and their soluble IP counterparts.

\section{PHOSPHOINOSITIDES CONTROL SIGNALING BY BINDING TO SPECIFIC PROTEIN DOMAINS}

All phosphoinositides contain a hydrophobic membrane-embedded diacylglyceride and a hydrophilic solvent-exposed IP moiety. The inositol ring hydroxyl groups can be stereo-specifically phosphorylated by phosphoinositidekinases. Most phosphatidylinositol-bisphosphate in the plasma membrane of unstimulated 
cells is phosphorylated at the inositol 4- and 5 -positions. This $\mathrm{PIP}_{2}$ comprises $<1 \%$ of the inner leaflet of the plasma membrane, contrasting with much more abundant phospholipids such as phosphatidylserine and phosphatidic acid (PA) (Lemmon 2008). Despite its low abundance, $\mathrm{PIP}_{2}$ is an important second messenger. It recruits and regulates multiple signaling proteins by binding to their pleckstrin homology $(\mathrm{PH})$, epsin N-terminal homology (ENTH), 4.1, ezrin, radixin, moesin (FERM), Tubby, or Phox-homology (PX) domains with varying affinities and specificities (McLaughlin et al. 2002). Due to the constitutive $\mathrm{PIP}_{2}$ availability in resting cells, these $\mathrm{PIP}_{2}$-associated proteins likely maintain signaling pathways in a preactivation state. Evidence supporting this notion in $\mathrm{T}$ cells comes from the inhibitory effects of $\mathrm{PIP}_{2}$ binding to the guanine nucleotide exchange factor, Vav (Han et al. 1998), and the guanine nucleotide activating factor, ArhGAP9, which maintains Rho-family GTPases in an inactive state (Ang et al. 2007; Ceccarelli et al. 2007).

\section{PHOSPHOINOSITIDE 3-KINASES CONVERT PIP $_{2}$ INTO PHOSPHATIDYLINOSITOL $(3,4,5)$ TRISPHOSPHATE}

Despite the importance of PIP2, much greater attention has been given to the products of $\mathrm{PIP}_{2}$ phosphorylation or $\mathrm{PIP}_{2}$ hydrolysis that are induced following receptor activation. $\mathrm{PIP}_{2}$ phosphorylation is mediated by PI3Ks. PI3Ks fall into four classes based upon their substrate specificity. Each class comprises one or more regulatory and catalytic subunits with partially distinct and overlapping functions (Fig. 2). Class II and III PI3Ks phosphorylate phosphatidylinositol (PI) into $\mathrm{PI}(3) \mathrm{P}$ and $\mathrm{PI}(3,4) \mathrm{P}_{2}$. Their functions in lymphocytes are largely unexplored. Class I PI3Ks phosphorylate $\mathrm{PIP}_{2}$ into $\mathrm{PIP}_{3}$, an inducible ligand that mediates recruitment and activation of various important signaling proteins. Class IA PI3Ks are activated by most stimulatory receptors on lymphocytes including $\mathrm{T}$ - and $\mathrm{B}$-cell antigen receptors (TCR, BCR), and co-stimulatory, Toll-like, and cytokine receptors (Vanhaesebroeck et al. 2005; Buitenhuis and Coffer 2009; Fruman and
Lipid Signaling in T-cell Development and Function

Bismuth 2009). Five regulatory (p50 $\alpha, \mathrm{p} 55 \alpha$, $\mathrm{p} 55 \gamma, \mathrm{p} 85 \alpha, \mathrm{p} 85 \beta)$ and three catalytic $(\mathrm{p} 110 \alpha$, $\beta$, and $\delta$ ) subunits participate in Class IA PI3K signaling. Recruitment of Class IA regulatory subunits via binding of their $\mathrm{SH} 2$ domains to receptor-induced tyrosine-phosphorylated ITAM motifs leads to colocalization of PI3K catalytic subunits with their substrate, membrane $\mathrm{PIP}_{2}$. In contrast, Class IB PI3Ks are activated downstream of G-protein-coupled receptors, including chemokine receptors. Class IB comprises two regulatory subunits ( $\mathrm{p} 101, \mathrm{p} 84 / 87$ )

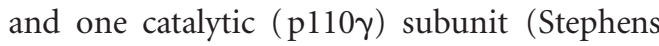
et al. 1994; Stoyanov et al. 1995; Stephens et al. 1997; Suire et al. 2005). Following GPCR engagement, class IB PI3K regulatory subunits bind through their C-terminal domains to $\mathrm{G} \beta \gamma$ subunits. Both class IA (Okkenhaug et al. 2002; Okkenhaug et al. 2006; Patton et al. 2006; Matheu et al. 2007; Liu et al. 2009a; Liu and Uzonna 2010; Soond et al. 2010) and class IB (Sasaki et al. 2000; Swat et al. 2006; Alcazar et al. 2007) PI3Ks have important functions in T-cell development and function. The T-cell phenotypes of mice with individual or combined PI3K subunit deficiencies are summarized in Table 1.

\section{THE SECOND MESSENGER PIP ${ }_{3}$ RECRUITS PROTEINS TO MEMBRANES BY BINDING TO THEIR PH DOMAINS}

Taken together, immunoreceptor-induced $\mathrm{PIP}_{3}$ generation is important for lymphocyte proliferation and differentiation (for reviews, see Juntilla and Koretzky 2008; Buitenhuis and Coffer 2009; Fruman and Bismuth 2009). PIP mediates the cellular effects of PI3K activation by recruiting effector proteins that stereospecifically bind to $\mathrm{PIP}_{3}$ through a subclass of pleckstrin homology or $\mathrm{PH}$ domains-protein modules of approximately 120 amino acids that were originally identified as a repeated domain in Pleckstrin (Haslam et al. 1993; Mayer et al. 1993). The mammalian genome contains approximately $250 \mathrm{PH}$ domain proteins. Although there is little amino acid sequence conservation among $\mathrm{PH}$ domains, they share a common $\beta$-barrel fold comprised of two $\beta$ 
Y.H. Huang and K. Sauer

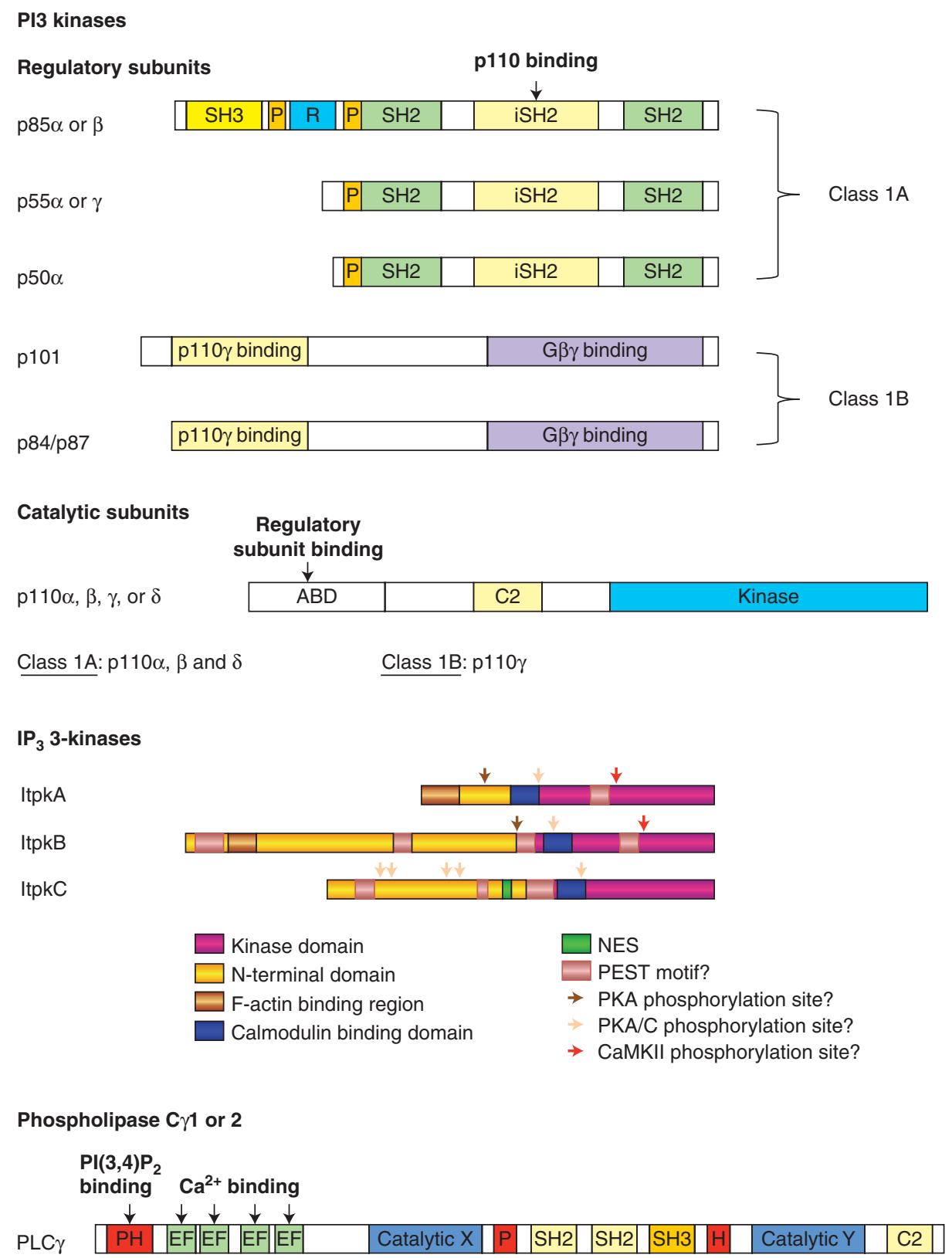

Figure 2. Schematic structures of key $\mathrm{PIP}_{2}$ or $\mathrm{IP}_{3}$ kinases and $\mathrm{PIP}_{2}$ lipases in lymphocytes. For details, see text.

sheets and a C-terminal $\alpha$-helical cap (Downing et al. 1994; Ferguson et al. 1994; Macias et al. 1994; Timm et al. 1994; Yoon et al. 1994). In approximately $60 \mathrm{PH}$ domains, the $\mathrm{N}$-terminal portion contains a pocket that binds phosphoinositols (Cozier et al. 2004; Hirata et al. 1998). These PH domains are divided into two classes. Class I PH domains bind with high affinity and specificity to $\mathrm{PI}(4,5) \mathrm{P}_{2}$, $\mathrm{PI}(3,4) \mathrm{P}_{2}, \mathrm{PIP}_{3}$, and/or $\mathrm{IP}_{4}$. Class II $\mathrm{PH}$ domains bind PIs more promiscuously and with lower affinity.

Different positively charged amino acid side chains in the PI-binding pocket of a $\mathrm{PH}$ 
Lipid Signaling in T-cell Development and Function

Table 1. Phenotypic consequences of deficiencies in phosphoinositol lipid metabolizing enzymes in lymphocytes.

\begin{tabular}{|c|c|}
\hline $\begin{array}{l}\text { Deficient- or functionally- } \\
\text { impaired protein(s) }\end{array}$ & T-cell phenotype \\
\hline \multicolumn{2}{|l|}{$\begin{array}{l}\text { PI3 Kinase Regulatory } \\
\text { Subunits }\end{array}$} \\
\hline $\begin{array}{l}\mathrm{p} 85 \alpha-(p i k 3 r 1) \text { deficient } \\
\text { mice }\end{array}$ & $\begin{array}{l}\text { Reduced T-cell development, reduced } \\
\text { migrational velocity, normal mature } \\
\text { T-cell function. }\end{array}$ \\
\hline $\begin{array}{l}\text { p85ß- (pik3r2) deficient } \\
\text { mice }\end{array}$ & $\begin{array}{l}\text { Normal T-cell development, reduced cell } \\
\text { velocity. Elevated anti-CD3/ } \\
\text { IL-2-induced proliferation in one } \\
\text { study. Defective peripheral T cell recall } \\
\text { responses and CD28 signaling in } \\
\text { another study. }\end{array}$ \\
\hline $\begin{array}{l}\mathrm{p} 85 \alpha, \mathrm{p} 55 \alpha, \mathrm{p} 50 \alpha(p i k 3 r 1) \\
\text { multi-deficient mice }\end{array}$ & None reported. Perinatal lethality. \\
\hline $\begin{array}{l}\mathrm{p} 85 \alpha, \mathrm{p} 55 \alpha, \mathrm{p} 50 \alpha(p i k 3 r 1) \\
\quad \& \mathrm{p} 85 \beta(p i k 3 r 2) \\
\text { multi-deficient T cells }\end{array}$ & $\begin{array}{l}\text { Largely normal T-cell development. } \\
\text { Impaired T cell } \mathrm{Ca}^{2+} \text { signaling, } \\
\text { proliferation and cytokines, defective } \\
\text { Treg function and Th2 responses but } \\
\text { normal Th1 responses, reduced cell } \\
\text { velocity and polarization. Sjoegren's } \\
\text { like autoimmune disease. }\end{array}$ \\
\hline
\end{tabular}

\section{PI3 Kinase Catalytic} Subunits $\mathrm{p} 110 \alpha^{-/-}$mice or p $110 \beta^{-/-}$mice p $110 \delta^{-/-}$mice p $110 \delta^{\text {D910A }}$ catalytically inactive mutant expressing mice p110 $\gamma^{-/-}$mice $\mathrm{p} 110 \gamma^{-/-} \mathrm{p} 110 \delta^{-/-}$or
p110 $\gamma^{-/-} \mathrm{p} 110 \delta^{\mathrm{D} 910 \mathrm{~A}}$
mice
Not determined. Embryonic lethal.

No major abnormalities.

Impaired TCR-induced $\mathrm{Ca}^{2+}$ signaling, proliferation, migration and cytokine production, reduced Th1, Th2 and Treg function. Protection from type 2 cytokine responses like airway hyperresponsiveness. Colitis, widespread autoimmunity.

Some controversies between groups. Impaired T-cell development and activation, proliferation, actin polymerization. Normal activation but impaired migration in another study. Similar cell velocity but with more turning. Reduced CD4 ${ }^{+}$ memory cell survival, autoantibody production, glomerulonephritis, and systemic lupus.

Impaired T-cell development, proliferation and cell survival, exaggerated Th2 over Th1 responses, high serum IgE levels.
References

(Matheu et al. 2007; Shiroki et al. 2007)

(Deane et al. 2004; Matheu et al. 2007; Alcazar et al. 2009)

(Fruman et al. 2000)

(Oak et al. 2006; Deane et al. 2007; Matheu et al. 2007; Fruman and Bismuth 2009)

(Buitenhuis and Coffer 2009)

(Clayton et al. 2002)

(Okkenhaug et al. 2002;

Okkenhaug et al. 2006; Patton et al. 2006; Nashed et al. 2007; Jarmin et al. 2008)

(Sasaki et al. 2000;

Rodriguez-Borlado et al. 2003; Barber et al. 2006; Alcazar et al. 2007; Martin et al. 2008;

Thomas et al. 2008; Fruman and Bismuth 2009)

(Webb et al. 2005; Swat et al. 2006; Ji et al. 2007) 
Y.H. Huang and K. Sauer

Table 1. Continued

Deficient- or functionallyimpaired protein(s)

T-cell phenotype

References

$I_{3}$ 3-Kinases

ItpkA $^{-/-}$mice

ItpkB $^{-/-}$mice

None reported.

Blocked T-cell development and thymocyte positive selection. Normal $\mathrm{IP}_{3}$-accumulation and $\mathrm{Ca}^{2+}$ signaling, but defective DAG production, Itk recruitment, and activation in thymocytes.

ItpkC $^{-/-}$mice
ItpkB $^{-/-}$ItpkC $^{-/-}$mice
ITPKC loss-of-function
polymorphism, humans
ITPKC knockdown, Jurkat
cells
ITPKC overexpression,
Jurkat cells
IPMK $^{-/}$mice
PIP $_{3} /$ IP $_{4}$ Phosphatases
SHIP $^{-/-}$mice
PTEN $^{+/-}$mice
Conditional PTEN
knockout in T cells in $_{\text {mice }}$

No thymic phenotype. Normal $\mathrm{IP}_{3}$ 3-kinase activity in thymocytes. Same T-cell developmental block as ItpkB $B^{-/-}$mice.

Associated with Kawasaki disease susceptibility.

Hyperactivation.

Reduced activation.

None reported. Embryonic lethal.

Altered Th1/Th2 ratio, reduced CD8 cytotoxicity. Shortened lifespan, splenomegaly, autoimmunity.

Hyperproliferative T cells. Increased tumor incidence, autoimmunity.

Impaired T-cell development, hyperresponsive to suboptimal TCR signals, increased cytokine production, Th2 bias, autoimmune pathology.

Conditional knockout: Impaired thymocyte positive and negative selection, regulatory $\mathrm{T}_{\text {reg }}$ cell development and function, TCR-induced peripheral T-cell proliferation and cytokine production. Autoimmune disease. Conventional knockout is embryonic lethal. Chimeric mice: Severe defects in early hematopoiesis.

No T-cell defect reported. Defects in mast cells, dendritic cells, osteoclasts, and neutrophils.
(Jun et al. 1998; Kim et al. 2009)

(Pouillon et al. 2003; Wen et al. 2004; Chamberlain et al. 2005; Huang et al. 2006; Huang et al. 2007; Jia et al. 2007; Marechal et al. 2007; Miller et al. 2007b; Huang et al. 2008; Jia et al. 2008a; Jia et al. 2008b; Miller et al. 2008; Miller et al. 2009)

(Pouillon et al. 2003)

(Pouillon et al. 2003)

(Onouchi et al. 2008)

(Onouchi et al. 2008)

(Onouchi et al. 2008)

(Frederick et al. 2005)

(Helgason et al. 1998; Tarasenko et al. 2007)

(Di Cristofano et al. 1999; Di Cristofano and Pandolfi 2000)

(Suzuki et al. 2001; Hagenbeek et al. 2004; Buckler et al. 2008)

(Ji et al. 1997; Shirane et al. 2001; Fu et al. 2010)

(Wang et al. 2000; Graham et al. 2007; Cremasco et al. 2008; Epple et al. 2008; Cremasco et al. 2010)

Continued 
Lipid Signaling in T-cell Development and Function

Table 1. Continued

\begin{tabular}{|c|c|c|}
\hline $\begin{array}{l}\text { Deficient- or functionally- } \\
\text { impaired protein(s) }\end{array}$ & T-cell phenotype & References \\
\hline $\mathrm{DGK} \alpha^{-/-}$mice & Hyper-responsive T cells. & $\begin{array}{l}\text { (Outram et al. 2002; Olenchock } \\
\text { et al. 2006) }\end{array}$ \\
\hline $\mathrm{DGK}^{-/-}$mice & Hyper-responsive T cells. & $\begin{array}{l}\text { (Zhong et al. 2003; Olenchock } \\
\text { et al. 2006) }\end{array}$ \\
\hline $\begin{array}{l}\mathrm{DGK} \alpha^{-/-} \mathrm{DGK} \xi^{-/-} \\
\text {mice }\end{array}$ & $\begin{array}{l}\text { Lymphopenia due to a partial block in } \\
\text { T-cell development. Reduced } \mathrm{T}_{\text {regs }} \text {, } \\
\text { peripheral T cell resistant to } \\
\text { anergy-induction. }\end{array}$ & $\begin{array}{l}\text { (Olenchock et al. 2006; Zha et al. } \\
\text { 2006; Guo et al. 2008) }\end{array}$ \\
\hline
\end{tabular}

domain determine its ligand specificity by interacting with specific negatively charged phosphate groups within the inositol ring. The Akt (Protein kinase B) and Tec protein kinase families are part of a small but immunologically important subset of $\mathrm{PH}$-domain-containing proteins whose activities are regulated by $\mathrm{PIP}_{3}$ binding, which colocalizes the kinases with their upstream activators (August et al. 1997; Heyeck et al. 1997; Stokoe et al. 1997). In addition, the Akt $\mathrm{PH}$ domain can also bind to $\mathrm{PI}(3,4) \mathrm{P}_{2}$ (Cozier et al. 2004; DiNitto and Lambright 2006; James et al. 1996; Lemmon 2008).

\section{$\mathrm{PIP}_{3}$ CONTROLS AKT FUNCTION IN LYMPHOCYTES}

Akt and its upstream activator PDK1 (Phosphoinositide-dependent kinase 1) are nonreceptor serine/threonine kinases of the AGC family. They regulate survival and proliferation of many cell types (Manning and Cantley 2007). Both kinase families are structurally relatively simple_containing only a kinase domain, a $\mathrm{PH}$ domain, and in the case of Aktl, a short hydrophobic motif. Before activation, the Akt and PDK1 PH domains seem to function in an inhibitory manner that is released upon membrane $\mathrm{PIP}_{3}$ binding (Stokoe et al. 1997; Gao and Harris 2006). Full PDK1 activation requires $\mathrm{PIP}_{3}$ binding to the $\mathrm{PDK} 1 \mathrm{PH}$ domain, which allows trans-phosphorylation of a Cterminal residue (Gao and Harris 2006). In the absence of lipid ligands, the Akt1 PH domain occludes access to the activation site, prohibiting its phosphorylation by PDK1 (Stokoe et al. 1997; Calleja et al. 2007). PHdomain-mediated PDK1 and Akt recruitment to membrane $\mathrm{PIP}_{3}$ leads to phosphorylation of the catalytic T-loop of Akt by PDK1, activating Akt (Stephens et al. 1998). A second kinase of uncertain identity phosphorylates the Akt C-terminal hydrophobic motif, leading to optimal Akt kinase activity.

There are three Akt paralogs in mammals (Akt1/2/3). All are expressed in lymphocytes and have partially redundant functions. Akt promotes cell survival primarily through inhibition of apoptosis. Akt can directly or indirectly inhibit the function of proapoptotic Bcl-2 family members by phosphorylation (del Peso et al. 1997; Gardai et al. 2004; Qi et al. 2006; Hubner et al. 2008). Akt also activates the transcription factor NF-kB (Madrid et al. 2000) and induces expression of antiapoptotic Bcl-2, FLIP, and IAP proteins (Wang et al. 1998; Panka et al. 2001). Akt, moreover, promotes cell proliferation by increasing cell metabolism (Frauwirth et al. 2002; Rathmell et al. 2003; Jacobs et al. 2008), facilitating protein translation (Dufner et al. 1999), and cell cycle progression (Liang et al. 2002; Shin et al. 2002; Viglietto et al. 2002). Consequently, genetic alterations that enhance Akt activity either directly or indirectly via amplification of PI3K activity often lead to cellular transformation (Liu et al. 2009b).

Akt1 and Akt2 are particularly important during early T-cell development (Juntilla et al. 2007; Juntilla and Koretzky 2008). CD4 and CD8 $\mathrm{T}$ cells develop from a common thymic 
progenitor through a series of developmental stages that can be partially characterized by differential cell-surface expression of the CD4 and CD8 coreceptors. At the early, CD4 ${ }^{-} \mathrm{CD} 8{ }^{-}$ double-negative (DN) stage, productive TCR $\beta$ gene rearrangement results in a pre-TCR signal that suppresses rearrangement of the second TCR $\beta$ allele and triggers proliferative expansion and progression to the $\mathrm{CD} 4^{+} \mathrm{CD} 8^{+}$doublepositive (DP) stage. During this process, the cells rearrange their TCR $\alpha$ chain genes. Successful TCR $\alpha$ protein expression results in pre-TCR replacement by a mature TCR composed of $\alpha$ and $\beta$ chains. Akt1 or Akt2 deficiency results in a two-fold reduction in thymic cellularity due to a partial block between DN and DP cells. In contrast, Akt 1 and Akt2 double-deficiency results in a 45-fold decrease in thymic cellularity (Juntilla et al. 2007). This highlights the importance of Akt kinases during the highly proliferative stage of thymic development.

\section{TEC FAMILY PROTEIN TYROSINE KINASES ARE KEY PIP ${ }_{3}$ EFFECTORS IN LYMPHOCYTES}

The expression of certain Tec family nonreceptor protein-tyrosine-kinases (TFKs) is restricted to specific immune cell types (Readinger et al. 2009). Itk and Rlk are largely restricted to $\mathrm{T}$ cells and NK cells. Btk is not expressed in these, but enriched in B cells, mast cells, and myeloid cells. Tec is broadly expressed in hematopoietic cells. Despite some functional redundancies, deficiency in individual TFKs causes profound functional defects (for a review, see Readinger et al. 2009). Itk deficiency causes defects in T-cell development and in certain peripheral T-cell functions (Liao and Littman 1995; Fowell et al. 1999; Schaeffer et al. 1999; Schaeffer et al. 2000; Schaeffer et al. 2001; Tomlinson et al. 2004; Finkelstein et al. 2005; Atherly et al. 2006; Broussard et al. 2006; Horai et al. 2007; Lucas et al. 2007).

At the DP stage, thymocytes are evaluated for the ability of their TCR to interact with self $\mathrm{MHC} /$ peptide complexes on the surfaces of thymic antigen-presenting cells. DP cells whose TCRs do not interact with sufficient strength or duration die by "neglect." DP cells whose TCRs interact moderately with selfMHC class I or II are positively selected to mature into CD8 or CD4 single positive T cells, respectively. DP cells carrying potentially autoreactive TCRs that interact too strongly or for an inappropriate duration with self-MHC are induced to die by "negative selection." A major unresolved question in immunological research is how TCR engagement can have such different outcomes.

Positively and negatively selecting TCR signals appear to activate the same proximal signaling molecules, including Itk. In Itk-deficient mice, the efficiencies of positive and negative selection are dramatically decreased (Liao and Littman 1995; Schaeffer et al. 2000). In contrast, Itk deficiency favors the accumulation of a nonconventional thymic $\mathrm{T}$ cell subset with an effector/ memory or "innate" phenotype, particularly in the CD8 lineage (Atherly et al. 2006; Broussard et al. 2006; Horai et al. 2007). In addition, TCR signals that normally induce negative selection can, under some circumstances, promote positive selection in Itk-deficient mice (Schaeffer et al. 2000). In mature T cells, Itk appears to be required to sustain $\mathrm{T}_{\mathrm{H}} 2$ responses (Fowell et al. 1999; Schaeffer et al. 2001).

TFKs have a relatively complex domain structure with an N-terminal PH domain, followed by a proline-rich Tec homology domain, Src homology 3 (SH3) and $\mathrm{SH} 2$ domains, and a C-terminal kinase domain. In Rlk, a missing $\mathrm{N}$-terminal PH domain is functionally substituted by palmitoylation, resulting in constitutive membrane association (Debnath et al. 1999). Membrane recruitment of the other TFKs predominantly depends on interactions between their $\mathrm{PH}$ domains and membrane $\mathrm{PIP}_{3}$ (Ching et al. 1999; Shan et al. 2000), together with interactions between their $\mathrm{SH} 2$ domains and adaptor proteins such as SLP-76 in T cells (Ching et al. 1999; Su et al. 1999). However, recent data may suggest that Btk membrane recruitment can also occur in a PH-domain-independent manner (Fruman and Bismuth 2009). Activation-induced association with cytosolic SLP76 and the membrane adaptor LAT colocalizes TFKs with their upstream activators, Src kinases, and their downstream target, PLC 1 
(Wange 2000; Qi and August 2007). Mechanistically, the consequences of TFK deficiency have primarily been attributed to defective PLCy phosphorylation and activation (Liu et al. 1998). In addition, TFKs appear required for Vav-dependent cytoskeletal organization and cell adhesion (Gomez-Rodriguez et al. 2007). However, TFK promotion of Vav function appears to involve TFK adaptor functions, rather than their kinase activities (Grasis et al. 2003; Dombroski et al. 2005).

\section{PHOSPHOLIPASE-C $\gamma$ HYDROLYZES PIP ${ }_{2}$ INTO THE SECOND MESSENGERS DIACYLGLYCEROL AND INOSITOL $(1,4,5)$ TRISPHOSPHATE}

$\mathrm{PI}(4,5) \mathrm{P}_{2}$ is a substrate for another immunologically important enzyme, phosphatidylinositolspecific phospholipase-C $\gamma$ (PLC $\gamma$ ). PLC $\gamma$ hydrolyzes $\mathrm{PIP}_{2}$ into its hydrophobic and hydrophilic components, the membrane-lipid diacylglycerol (DAG) and soluble inositol $(1,4,5)$ trisphosphate $\left(\mathrm{IP}_{3}\right)$. Both are second messengers that regulate proteins through specific binding domains.

The two mammalian PLC $\gamma$ isoforms, PLC $\gamma 1$ and 2, have partially overlapping expression patterns and functions (Wilde and Watson 2001). T cells exclusively express PLC $\gamma 1$. Tcell-specific PLC $\gamma 1$-deletion impaired thymocyte positive and negative selection, regulatory $\mathrm{T}_{\text {reg }}$ cell development and function, TCRinduced peripheral T-cell proliferation, and cytokine production (Fu et al. 2010). Defective TCR activation of the MAP kinases Erk and Jnk, and of the transcription factors NFAT, AP-1, and $\mathrm{NF}-\kappa \mathrm{B}$ indicates the broad importance of PLC $\gamma 1$ in TCR signaling through several pathways. Autoimmune disease symptoms show the physiological importance of PLC $\gamma 1$ in T cells (Fu et al. 2010). Severe blocks in T-cell development and late onset autoimmunity in mice expressing a PLC $\gamma 1$-binding-deficient LAT allele indicate the importance of LAT interactions for PLCy1 function (Sommers et al. 2002; Sommers et al. 2005). Finally, severe defects in early hematopoiesis in chimeric mice generated with PLC $\gamma 1$-deficient embryonic stem cells suggest important PLCy1 functions in hematopoietic stem or progenitor cells (Shirane et al. 2001). In contrast, PLCy2-deficient mice are viable with specific defects in B cells, mast cells, dendritic cells, osteoclasts, and neutrophils (Wang et al. 2000; Graham et al. 2007; Cremasco et al. 2008; Epple et al. 2008; Cremasco et al. 2010).

PLC $\gamma 1 / 2$ have complex domain structures with an N-terminal PH domain, followed by a number of EF hands, a catalytic domain that is split by an internal regulatory domain, and a C-terminal $\mathrm{Ca}^{2+}$-binding-C2 domain (Fig. 2). The regulatory domain contains a core of two tandem SH2 domains and an $\mathrm{SH} 3$ domain that is flanked by a split $\mathrm{PH}$ domain. This split $\mathrm{PH}$ domain can self-associate to form a functional $\mathrm{PH}$ domain, or associate in trans with a split $\mathrm{PH}$ domain in TRPC-family $\mathrm{Ca}^{2+}$ channels (van Rossum et al. 2005). Either one or both $\mathrm{PH}$ domains contribute to PLC $\gamma 1$ membrane association by binding to $\mathrm{PIP}_{3}$ (Bae et al. 1998; Falasca et al. 1998). Additional interactions are provided by the other modular domains. Once PLC $\gamma 1$ is at the membrane, phosphorylation of tyrosine residues within its regulatory domain by TFKs induces PLC $\gamma 1$ activation. Recent studies suggest that this requires phosphotyrosine-independent PLC $\gamma 1$ SH2 domain binding to a noncanonical ligand motif in Itk (Joseph et al. 2007; Min et al. 2009).

\section{DIACYLGLYCEROL CONTROLS Ras AND PKC ACTIVATION IN LYMPHOCYTES}

The membrane second messenger, DAG, propagates signals via membrane recruitment of cytosolic signaling proteins by binding to their $\mathrm{C} 1$ domains, cysteine-rich domains of approximately 50 amino acids. Two $\beta$-sheets harbor the DAG-binding cavity.

Several well-characterized DAG-effector families include Ras guanine-nucleotide-exchangefactors/releasing proteins (RasGRPs), protein kinase C-related kinases (PKCs, PKD), chimaerin Rho/Rac-GTPase-activating proteins (Yang and Kazanietz 2007), Munc13 proteins (Betz et al. 1998), and diacylglycerol kinases (DGKs). There is some effector selectivity for different DAG species that differ in their subcellular localization. 
For example, RasGRPs preferentially bind to DAG in Golgi membranes (Carrasco and Merida 2004). PKCs preferentially bind to DAG in the plasma membrane (Spitaler et al. 2006).

RasGRP membrane recruitment by DAG colocalizes these Ras activators with their substrate, inducing release of Ras-bound GDP, GTP binding, and Ras activation. Ras then activates the kinase Raf, which activates the downstream Erk cascade. The four mammalian RasGRPs 1-4 have partially overlapping expression patterns and partially redundant functions. T cells predominantly express RasGRP1, the main mediator of TCR-induced Ras/Erk activation (Dower et al. 2000; Priatel et al. 2002). RasGRP1 deficiency causes a significant block of T-cell development with strong defects in positive, and some defects in negative selection (Dower et al. 2000; Priatel et al. 2002). However, this developmental block is incomplete and can be partially rescued by strong TCR activation (Priatel et al. 2006). Nevertheless, a moderate lymphopenia occurs due to T-cell exhaustion (Priatel et al. 2007). Interestingly, $\mathrm{T}_{\text {reg }}$ cells accumulate in the periphery of RasGRP1-deficient mice, despite perturbed $\mathrm{T}_{\text {reg }}$ development (Chen et al. 2008).

In contrast to RasGRPs, DAG-mediated membrane recruitment allosterically induces PKC activitation by abrogating an autoinhibitory association between the PKC pseudo-substrate and substrate-binding domains (Rosse et al. 2010). DAG promotes activation of classic (PKC $\alpha, P K C \beta I, P K C \beta I I, P K C \gamma)$, novel (PKC $\delta, \mathrm{PKC} \varepsilon, \mathrm{PKC} \eta, \mathrm{PKC} \theta)$, and atypical PKCs $(\mathrm{PKC} \xi, \lambda / \iota)$. However, classic and novel PKCs also require $\mathrm{Ca}^{2+}$ binding to their $\mathrm{C} 2$ domains (Rosse et al. 2010). Multiple studies have shown essential PKC roles in lymphocyte development and function (for reviews, see Isakov and Altman 2002; Barouch-Bentov and Altman 2006; Manicassamy et al. 2006). In particular, PKCA is important for TCR signaling and required for thymocyte-positive selection (Morley et al. 2008). Incomplete developmental defects likely reflect redundancy among thymocyte-expressed PKCs.

Several recent publications suggest important functions for chimaerins in TCR signaling,
T-cell adhesion, and chemotaxis that involve their ability to inactivate Rac (Siliceo et al. 2006; Caloca et al. 2008; Siliceo and Merida 2009). No munc13 protein roles in the immune system have been reported.

\section{DIACYLGLYCEROL KINASES CONVERT DAG INTO PHOSPHATIDIC ACID}

Aside from their production by PLC $\gamma$ in lymphocytes, DAG levels are also regulated through their phosphorylation into phosphatidic acid (PA) by DAG kinases (DGKs). In T cells, this down-regulates PKC and RasGRP functions and TCR-induced-Erk activation (reviewed in Zhong et al. 2008). However, in many cell types, receptor-induced $\mathrm{PA}$ generation activates a series of PA-effector proteins with various functions, including vesicular trafficking, cell survival, and proliferation (Wang et al. 2006).

The ten mammalian DGKs form five groups based on their domain structure (Fig. 3). All DGKs have two to three C1 domains and a kinase domain. However, these $\mathrm{C} 1$ domains do not necessarily participate in DAG binding. Instead, the domains that distinguish the DGK types direct differential localization or activation requirements. $\mathrm{T}$ cells express at least three DAG kinases: DGK $\alpha$ (type I), $\delta$ (type II), and $\xi$ (type IV). DGK $\alpha$ has an $\mathrm{N}$-terminal RVH domain and two EF hands. $\mathrm{Ca}^{2+}$ binding to these three domains induces DGK $\alpha$ activation. DGK $\delta$ has an N-terminal PH domain, two EF hands, and a C-terminal SAM domain. The $\mathrm{PH}$ domain facilitates DAG binding. The SAM domain mediates DGK $\delta$ oligomerization and ER targeting. DGK $\xi$ has a central MARCKS domain, multiple ankyrin repeats, and a Cterminal PDZ-BM domain. The MARCKs domain contains a nuclear localization sequence. The PDZ-BM domain of DGK $\xi$ regulates Rac activity and membrane ruffling.

DGK $\alpha$ and DGK $\xi$ cooperatively downregulate $\mathrm{T}$-cell activation and facilitate $\mathrm{T}$-cell tolerance (Guo et al. 2008). Different T-cell developmental and activation stages express different DGK $\alpha$ and DGK $\xi$ splice variants (Macian et al. 2002). DGK $\alpha$ - (Outram et al. 


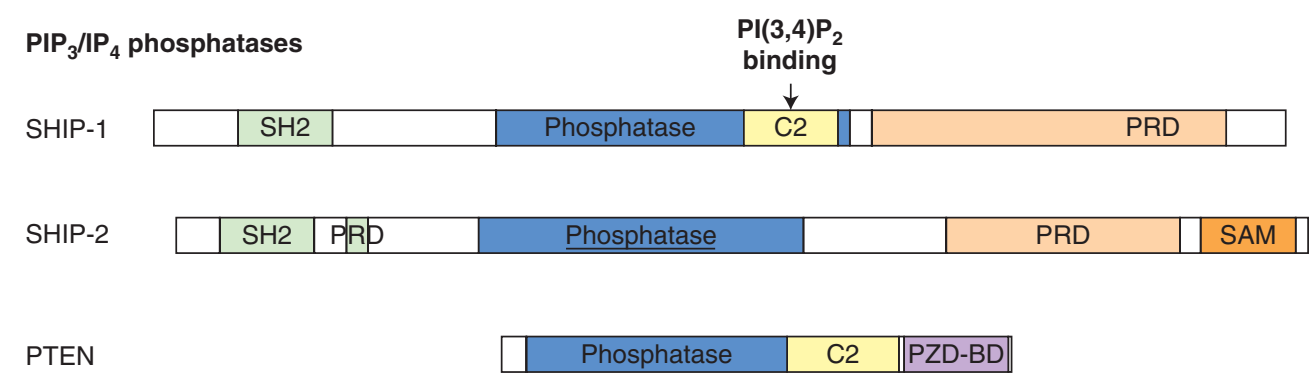

DAG kinases
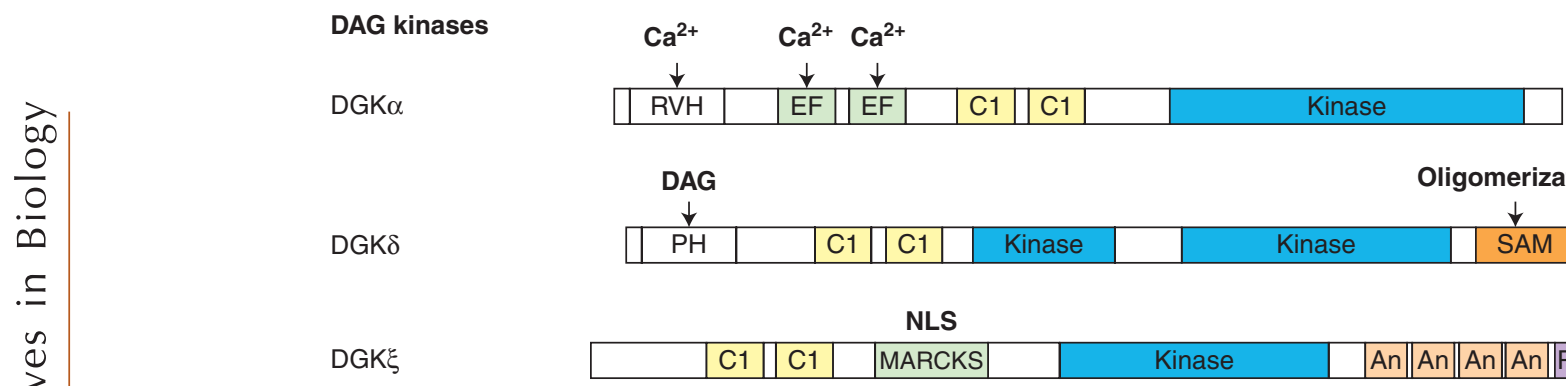

Figure 3. Schematic structures of key $\mathrm{PIP}_{3}$ or $\mathrm{IP}_{4}$ phosphatases and DAG kinases in lymphocytes. For details, see text.

2002; Olenchock et al. 2006) or DGK - (Zhong et al. 2003; Olenchock et al. 2006) deficient mice have increased DAG-dependent signaling and produce hyper-responsive T cells. DGK $\alpha / \xi$ double deficiency causes lymphopenia due to a partial block in T-cell development (Guo et al. 2008). The peripheral $\mathrm{T}$ cells contain reduced $\mathrm{T}_{\text {reg }}$ proportions and are resistant to anergy induction (Olenchock et al. 2006; Zha et al. 2006). Therefore, limiting DAG function in $\mathrm{T}$ cells is of great physiological importance, although defective PA production may contribute to the phenotype (Zhong et al. 2008).

\section{IP $_{3}$ MEDIATES ANTIGEN-RECEPTOR-} INDUCED $\mathrm{Ca}^{2+}$ MOBILIZATION AND CAN ACT AS A PRECURSOR FOR HIGHER-ORDER INOSITOL PHOSPHATES IN LYMPHOCYTES

$\mathrm{Ca}^{2+}$ is a rapid and robust, soluble second messenger with multiple downstream effectors (Feske 2007; Oh-hora and Rao 2008; Vig and Kinet 2009). mM extracellular $\mathrm{Ca}^{2+}$ concentrations contrast with $\mathrm{nM}$ cytosolic $\mathrm{Ca}^{2+}$ concentrations that are tightly maintained by pumps, which sequester $\mathrm{Ca}^{2+}$ into the extracellular space or intracellular storage compartments (Feske 2007; Oh-hora and Rao 2008). Following TCR engagement, $\mathrm{Ca}^{2+}$ signaling is initiated by the soluble product of $\mathrm{PIP}_{2}$ hydrolysis, $\operatorname{Ins}(1,4,5) \mathrm{P}_{3}$ (here $\left.\mathrm{IP}_{3}\right) . \mathrm{IP}_{3}$ binding to receptors in the $\mathrm{ER}$ membrane releases the stored $\mathrm{Ca}^{2+}$ into the cytosol (Taylor et al. 2009). Subsequent sensing of the store depletion by STIM proteins induces STIM translocation to the plasma membrane, where STIM-induced opening of ORAI-family $\mathrm{Ca}^{2+}$ channels triggers a store-operated $\mathrm{Ca}^{2+}$ entry (SOCE). This causes a sustained increase of the cytoplasmic $\mathrm{Ca}^{2+}$ concentration that is essential for T-cell activation (Feske 2007; Oh-hora and Rao 2008; Vig and Kinet 2009).

Cytosolic $\mathrm{Ca}^{2+}$ binds to proteins with $\mathrm{C} 2$ domains and $\mathrm{EF}$ hands, inducing conformational changes that alter activity (Niki et al. 1996). Important examples with EF hands are the cytosolic adapter Calmodulin and STIM proteins (Feske 2007; Oh-hora and Rao 2008; Vig and Kinet 2009). 
Y.H. Huang and K. Sauer

\section{$I_{3}$ CONVERSION INTO INOSITOL $(1,3,4,5)$ TETRAKISPHOSPHATE BY $\mathrm{IP}_{3}$ 3-KINASES CONTROLS LYMPHOCYTE DEVELOPMENT AND FUNCTION}

Aside from mediating receptor-induced $\mathrm{Ca}^{2+}$ mobilization, $\mathrm{IP}_{3}$ can also act as a precursor for other IPs. A key step in their generation is $\mathrm{IP}_{3}$ phosphorylation at its 3-position into $\mathrm{IP}_{4}$ by $\mathrm{IP}_{3}$ 3-kinases (IP3Ks). Mammals have four IP3Ks: the closely related ITPK-family members ItpkA/B/C and the unrelated IP multikinase (IPMK).

Genetic studies in yeast and biochemical data have suggested many potential $\mathrm{IP}_{4}$ functions (Irvine 2001; Irvine and Schell 2001; Nalaskowski and Mayr 2004; Pattni and Banting 2004; Irvine 2005; Irvine et al. 2006; York 2006; Otto et al. 2007; Huang et al. 2008; Jia et al. 2008b; Miller et al. 2008; Sauer and Cooke 2010; Schell 2010). Much research has explored potential IP3K roles in regulating $\mathrm{Ca}^{2+}$ mobilization either by controlling $\mathrm{IP}_{3}$ turnover, or through distinct functions of $\mathrm{IP}_{4}$ or $\mathrm{IP}_{4}$-derived other IPs. The results caused a long-standing controversy that could be attributed to differences in cell type, stimulation regimen, or experimental conditions. Studies with human Jurkat T cells suggest that $\mathrm{IP}_{4}$ can sustain TCR-induced $\mathrm{IP}_{3}$ accumulation and $\mathrm{Ca}^{2+}$ mobilization through competitive inhibition of an inositol 5-phosphatase (Hermosura et al. 2000). Moreover, a recent study suggested that ITPKC knockdown in Jurkat cells promotes TCRinduced activation of the $\mathrm{Ca}^{2+}$-effector NFAT and IL-2 production (Onouchi et al. 2008). These data are consistent with one IP3K role in controlling $\mathrm{IP}_{3}$ levels or function. The precise mechanism, identity of the 5-phosphatase, and physiological relevance remain unclear. Normal anti-TCR antibody-induced $\mathrm{IP}_{3}$ accumulation and $\mathrm{Ca}^{2+}$ mobilization in ItpkB-deficient thymocytes suggest that ItpkB may not regulate $\mathrm{Ca}^{2+}$ mobilization in murine thymocytes (Pouillon et al. 2003; Wen et al. 2004). However, $\mathrm{IP}_{4}$ levels and total IP3K activity were only approximately $50 \%$ reduced. Thus, other IP3Ks likely contribute to $\mathrm{IP}_{4}$ production in thymocytes, and the consequences of complete
$\mathrm{IP} 3 \mathrm{~K} / \mathrm{IP}_{4}$ deficiency on $\mathrm{Ca}^{2+}$ mobilization still needs to be determined.

$\mathrm{IP}_{4}$ chemically resembles the $\mathrm{PH}$-domainbinding headgroup of $\mathrm{PIP}_{3}$, and less well those of $\mathrm{PI}(4,5) \mathrm{P}_{2}$ and $\mathrm{PI}(3,4) \mathrm{P}_{2}$. Not surprisingly, $\mathrm{IP}_{4}$ can bind to some of the protein domains that bind to these phosphoinositides. This property is often used to facilitate PH domain crystallization for X-ray structure determination (Lemmon 2008). Biochemical data suggest that $\mathrm{IP}_{4}$ binding to the PH domains of Ras GTPaseactivating proteins (RASA2/GAP1 ${ }^{\mathrm{m}}, \mathrm{RASA} 3 /$ $\mathrm{GAP}^{\mathrm{IP} 4 \mathrm{BP}}$ ) (Cullen et al. 1995; Cozier et al. 2000b), BTK, AKT, or certain regulators of vesicular trafficking (synaptotagmins, centaurin- $\alpha 1$ / $\mathrm{p} 42^{\mathrm{IP} 4}$ ), might inhibit their membrane recruitment, activation, or protein interactions. However, until recently, the physiological relevance of these findings was unknown.

Lymphocytes predominantly express two Itpks, ItpkB and ItpkC (Vanweyenberg et al. 1995; Wen et al. 2004). ItpkC is broadly expressed by many tissues. ItpkB expression appears restricted to hematopoietic cells and the brain (Wen et al. 2004; Jia et al. 2008a). ItpkB-deficient mice recently unveiled the physiological importance of ItpkB in lymphocyte development and activation (Table 1) (Pouillon et al. 2003; Wen et al. 2004). These mice are profoundly immunocompromised due to severe peripheral T-cell deficiency (Pouillon et al. 2003; Wen et al. 2004), reduced numbers and defective activation of B cells (Marechal et al. 2007; Miller et al. 2007a; Miller et al. 2009), and increased numbers of functionally perturbed neutrophils (Jia et al. 2007). Several recent reviews describe current models for ItpkB function in B cells and neutrophils (Huang et al. 2008; Jia et al. 2008b; Miller et al. 2008; Sauer and Cooke 2010). Here, we highlight the function of $\mathrm{IP}_{4}$ in $\mathrm{T}$ cells.

ItpkB-deficient mice have a block of T-cell development due to defective positive selection (Pouillon et al. 2003; Wen et al. 2004). Whether negative selection is affected is still unclear (Sauer and Cooke 2010). Selected effectors of both $\mathrm{IP}_{3}\left(\mathrm{Ca}^{2+}\right)$ and DAG are specifically required for positive selection. Deficiency in Calcineurin $\mathrm{B}, \mathrm{a} \mathrm{Ca}^{2+}$-dependent phosphatase 
that activates NFAT (Neilson et al. 2004; Gallo et al. 2007), or in RasGRP1, partially blocks positive selection (Dower et al. 2000; Priatel et al. 2002). Intriguingly, ItpkB deficiency blocks positive selection much more profoundly in a manner that depends on the ability of ItpkB to generate $\mathrm{IP}_{4}$ (Huang et al. 2007). Normal $\mathrm{IP}_{3}$ levels and $\mathrm{Ca}^{2+}$ mobilization in ItpkB-deficient thymocytes argue against significant contributions by these messengers. Instead, the block results from an inability of ItpkB-deficient thymocytes to produce sufficient DAG amounts in response to mild, positively selecting TCR stimuli (Huang et al. 2007). Consequently, mild TCR engagement induced Ras/Erk activation is impaired in ItpkB-deficient DP cells. This likely contributes to defective positive selection (Starr et al. 2003; McGargill et al. 2009). Addition of the DAG analog, PMA, restored Erk activation and allowed ItpkB-deficient CD4 and CD8 Tcell maturation (Huang et al. 2007). Thus, $\mathrm{IP}_{4}$ is required for DAG-induced Erk activation in response to positively selecting TCR stimuli. Yet, how does $\mathrm{IP}_{4}$ promote DAG accumulation?

\section{SOLUBLE IP ${ }_{4}$ CONTROLS ITK-PH-DOMAIN BINDING TO PIP 3 IN THYMOCYTES}

Mechanistic analyses revealed that $\mathrm{IP}_{4}$ is required for membrane recruitment and subsequent activation of the TFK Itk following mild TCR stimulation (Huang et al. 2007). This was surprising since generation of $\mathrm{PIP}_{3}$, the established membrane ligand for the Itk $\mathrm{PH}$ domain, was thought to be the limiting factor for Itk membrane localization. In vitro analyses then showed that low $\mu \mathrm{M} \mathrm{IP}_{4}$ concentrations, as previously found in TCR-stimulated T cells (Imboden and Pattison 1987), promoted Itk or Itk-PH-domain binding to $\mathrm{PIP}_{3}$ (Huang et al. 2007). Very high, likely super-physiological $\mathrm{IP}_{4}$ concentrations, competed with $\mathrm{PIP}_{3}$ binding. The ability of the Itk-PH domain to oligomerize (Huang et al. 2007) then resulted in a model where $\mathrm{IP}_{4}$ binding to one Itk-PH domain in a multimeric Itk complex induced conformational changes in all $\mathrm{PH}$ domains within the complex that allosterically increase
Lipid Signaling in T-cell Development and Function

their affinities for $\mathrm{PIP}_{3}$ and $\mathrm{IP}_{4}$. This promotes $\mathrm{PIP}_{3}$ binding, as long as $\mathrm{IP}_{4}$ is not in excess over $\mathrm{PIP}_{3}$. Here, $\mathrm{IP}_{4}$ catalyzes $\mathrm{PIP}_{3}$ binding at low, but competes with it at very high concentrations (Sauer and Cooke 2010). These findings identified Itk as the first physiological $\mathrm{IP}_{4}$ "receptor" and unveiled the first physiological $\mathrm{IP}_{4}$ function as a second messenger that controls Itk membrane recruitment and activation downstream of the TCR (Irvine 2007). They suggest that $\mathrm{IP}_{4}$ and $\mathrm{PIP}_{3}$ act as partners where soluble $\mathrm{IP}_{4}$ controls the ability of its membrane lipid counterpart to interact with the Itk-PH domain. It is exciting to hypothesize that this new principle of regulating $\mathrm{PH}$-domain function through an interplay of a soluble IP and its phosphoinositide-lipid partner has broader relevance in biological signaling. Indeed, $\mathrm{IP}_{4}$ could have similar bimodal effects on $\mathrm{PIP}_{3}$ binding to the Tec- and RASA3-PH domains, but whether this is physiologically relevant still needs to be determined (Huang et al. 2007). In neutrophils, $\mathrm{IP}_{4}$ has recently been suggested to inhibit Akt-PH domain interactions with membrane $\mathrm{PIP}_{3}$ or $\mathrm{PI}(3,4) \mathrm{P}_{2}$ (Jia et al. 2007). Loss of this function may contribute to an accumulation of granulocyte-macrophage progenitors and functionally-impaired neutrophils in ItpkB ${ }^{-/}$mice (Jia et al. 2007; Jia et al. 2008a; Jia et al. 2008b). On the other hand, $\mathrm{IP}_{4}$ did not affect PLC $\gamma 1$ binding to $\mathrm{PIP}_{3}$, which is mediated through its classic- and split-PH domains (Fig. 2) (Huang et al. 2007). Thus, not all $\mathrm{PIP}_{3}$-binding $\mathrm{PH}$ domains may be subject to $\mathrm{IP}_{4}$ control. One possible explanation is that the affinities of a given $\mathrm{PH}$ domain for $\mathrm{PIP}_{3}$ and $\mathrm{IP}_{4}$ can differ, with some $\mathrm{PH}$ domains preferring $\mathrm{IP}_{4}$ or $\mathrm{PIP}_{3}$, possibly due to differential contributions of the 1phosphate or the lipid environment to the binding free energy (DiNitto and Lambright 2006).

Finally, it is important to keep in mind that $\mathrm{IP}_{4}$ can be a precursor for multiple soluble IPs in mammalian cells. Some of these have been found in lymphocytes (for reviews, see Sauer et al. 2009; Sauer and Cooke 2010). Hence, some aspects of the ItpkB ${ }^{-/-}$phenotype might reflect deficiencies in other IPs.

Due to the blocked T-cell development in ItpkB-deficient mice, analyses of specific ItpkB 
functions in peripheral $\mathrm{T}$ cells will require conditionally ItpkB-deficient mice. However, studies linking ItpkC loss-of-function to augmented Jurkat cell activation and human Kawasaki disease support an $\mathrm{IP}_{4}$ role in regulating peripheral T-cell activation (Onouchi et al. 2008).

\section{PHOSPHATASES CONTROL PIP 3 AND IP 4 TURNOVER}

$\mathrm{PIP}_{3}$ levels are down-regulated by lipid phosphatases, including PTEN and SHIP1/2 in lymphocytes (Figs. 1 and 3; Table 1) (Harris et al. 2008). PTEN reverses the PI3K reaction and is generally thought to limit PI3K function. SHIP $1 / 2$ remove the $\mathrm{PIP}_{3}$ 5-phosphate, generating $\mathrm{PI}(3,4) \mathrm{P}_{2}$ and also down-modulating $\mathrm{PIP}_{3}$ levels (Damen et al. 1996; Kavanaugh et al. 1996; Lioubin et al. 1996). However, effectors such as Akt that predominantly bind to the inositol 3/4-phosphates may continue to be recruited and activated by $\mathrm{PI}(3,4) \mathrm{P}_{2}$. Thus, differential use of PTEN and SHIP1/2 can selectively alter the activities of a subset of $\mathrm{PIP}_{3}$ effectors, qualitatively changing PI3K responses.

Complete PTEN deficiency in mice results in embryonic lethality (Di Cristofano et al. 1998). PTEN hemizygosity, or conditional deficiency caused T-cell hyperproliferation, autoimmunity, and increased tumor incidence (Di Cristofano et al. 1999; Di Cristofano and Pandolfi 2000). PTEN deletion in T cells revealed the importance of precise $\mathrm{PIP}_{3}$ regulation for T-cell development through defective positive and negative selection (Suzuki et al. 2001). PTEN-deficient peripheral T cells were hyperresponsive to suboptimal TCR stimulation and less dependent on co-stimulation, resulting in autoimmune pathology (Suzuki et al. 2001). Activated $\mathrm{T}$ cells secreted increased cytokine amounts (Suzuki et al. 2001) and showed a bias toward the $\mathrm{T}_{\mathrm{H}} 2$ lineage (Buckler et al. 2008). Thus, $\mathrm{PIP}_{3}$ down-regulation by PTEN is required for limiting $\mathrm{T}$-cell responses and maintaining self-tolerance.

$\mathrm{PIP}_{3}$ dephosphorylation at the 5-position by SHIP $1 / 2$ is also important for T-cell tolerance. However, while the effects of SHIP deficiency partially overlap with those of PTEN deficiency, the additional importance of generating $\mathrm{PI}(3,4) \mathrm{P}_{2}$ is evident from the additional shortened lifespan of SHIP-deficient mice (Helgason et al. 1998). SHIP-deficient CD4 T cells have an altered Th1/Th2 cell ratio. SHIPdeficient CD8 T cells are less cytotoxic (Tarasenko et al. 2007). Thus far, these phenotypes have been attributed to defective $\mathrm{PIP}_{3}$ conversion into $\mathrm{PI}(3,4) \mathrm{P}_{2}$.

However, in vitro, both SHIPs and PTEN can dephosphorylate $\mathrm{IP}_{4}$ into $\mathrm{I}(1,3,4) \mathrm{P}_{3}$ or Ins $(1,4,5) \mathrm{P}_{3}$, respectively (Fig. 1) (Erneux et al. 1998; Maehama and Dixon 1998; Pesesse et al. 1998; Caffrey et al. 2001). Whether this is relevant in vivo is unknown. If it were, then the phenotypes of $\mathrm{PTEN}^{-/-}$or $\mathrm{SHIP}^{-/-}$ mice might need reinterpretation to consider potential contributions of perturbed $\mathrm{IP}_{4}$ downregulation. On the other hand, the presence of an $\mathrm{IP}_{4}$-inhibited 5-phosphatase in Jurkat cells that lack SHIP and PTEN (and also show hyperactivation) suggests that other phosphatases might also regulate $\mathrm{IP}_{4}$ levels in T cells (Hermosura et al. 2000).

\section{CONCLUDING REMARKS}

We have highlighted the importance of phosphoinositol signaling in lymphocytes, focusing on $\mathrm{T}$ cells. The importance of phosphoinositide lipids and of the $\mathrm{Ca}^{2+}$-mobilizing soluble $\mathrm{I}(1,4,5) \mathrm{P}_{3}$ in lymphocyte signaling have long been established, although many open questions remain. For example, what influence do the specific fatty acids in a phosphoinositide have? There is evidence that many different fatty acids can be found in a given phosphoinositide isomer. They might control where it is located or other aspects of its function. Is $\mathrm{PIP}_{3}$ really a universe of diverse molecules that differ in their fatty acid moieties and, possibly, functions?

More recent data unveiled important functions for the lipids DAG and PA, and for soluble $\mathrm{IP}_{4}$ in lymphocyte development and function. Some insight into the molecular mechanisms through which these novel messengers act has been gained, but our understanding of their molecular functions is far from complete. In 
particular, the roles of additional DAG effectors other than RasGRPs and PKCs in T cells need assessment, and the molecular mechanisms through which PA contributes to DGK function in lymphocytes are only beginning to be understood (Zhong et al. 2008).

One of the most intriguing, possibly broadly relevant, recent findings is the ability of $\mathrm{IP}_{4}$ to control $\mathrm{PIP}_{3}$ interactions with its effectors. Because $\mathrm{PIP}_{3}$ is the key mediator of PI3K, PTEN, and SHIP function, $\mathrm{IP}_{4}$ might ultimately act to control the functions of these important enzymes. Biochemically, PI3K and IP3Ks catalyze the very same reaction: phosphorylation of the inositol 3-position. Physiologically, they create the Tessa Virtue and Scott Moir, respectively, of a couple of second messengers whose dance in the cellular ice ring is reminiscent of the intricacy and elegance of its 2010 Winter Olympics counterpart. In DP thymocytes, the dance establishes a feedback loop of Itkmembrane recruitment and PLC $\gamma 1$ activation that is essential to allow mild TCR stimuli to cause sufficient DAG production, such that Ras/Erk can be activated and trigger positive selection (Huang et al. 2007; Sauer and Cooke 2010). It will be important to explore how broadly relevant $\mathrm{PIP}_{3}$ control through soluble $\mathrm{IP}_{4}$ is in other cell types and downstream of other receptors. Moreover, clarifying what determines whether a $\mathrm{PIP}_{3}$-binding protein domain is subject to $\mathrm{IP}_{4}$ control remains a challenging and important question. Finally, it will be exciting to determine the functions of the other higher-order IPs found in lymphocytes (Sauer et al. 2009; Sauer and Cooke 2010), and to determine which ones are $\mathrm{IP}_{4}$-derived and might, thus, mediate aspects of $\mathrm{IP}_{4}$ function. Clearly, exploring phosphoinositide-lipid signaling and the functions of the soluble IP code in lymphocytes will remain an exciting and important research area for years to come.

\section{ACKNOWLEDGMENTS}

We thank Claire Conche and Sabine Siegemund for critical reading of the manuscript and valuable comments. K.S. is supported by NIH grants AI070845 and GM088647, and by Scholar
Lipid Signaling in T-cell Development and Function

Award 1440-11 from The Leukemia \& Lymphoma Society. The authors declare no competing financial interests.

\section{REFERENCES}

Alcazar I, Cortes I, Zaballos A, Hernandez C, Fruman DA, Barber DF, Carrera AC. 2009. p85beta phosphoinositide 3-kinase regulates CD28 coreceptor function. Blood 113: 3198-3208.

Alcazar I, Marques M, Kumar A, Hirsch E, Wymann M, Carrera AC, Barber DF. 2007. Phosphoinositide 3-kinase gamma participates in $\mathrm{T}$ cell receptor-induced $\mathrm{T}$ cell activation. J Exp Med 204: 2977-2987.

Alcazar-Roman AR, Wente SR. 2008. Inositol polyphosphates: a new frontier for regulating gene expression. Chromosoma 117: 1-13.

Ang BK, Lim CY, Koh SS, Sivakumar N, Taib S, Lim KB, Ahmed S, Rajagopal G, Ong SH. 2007. ArhGAP9, a nove MAP kinase docking protein, inhibits Erk and p38 activation through WW domain binding. J Mol Signal 2: 1.

Atherly LO, Lucas JA, Felices M, Yin CC, Reiner SL, Berg LJ. 2006. The Tec family tyrosine kinases Itk and Rlk regulate the development of conventional $\mathrm{CD}^{+}{ }^{+} \mathrm{T}$ cells. Immunity 25: 79-91.

August A, Sadra A, Dupont B, Hanafusa H. 1997. Srcinduced activation of inducible $\mathrm{T}$ cell kinase (ITK) requires phosphatidylinositol 3-kinase activity and the Pleckstrin homology domain of inducible $\mathrm{T}$ cell kinase. Proc Natl Acad Sci U S A 94: 11227-11232.

Bae YS, Cantley LG, Chen CS, Kim SR, Kwon KS, Rhee SG. 1998. Activation of phospholipase C-gamma by phosphatidylinositol 3,4,5-trisphosphate. J Biol Chem 273: 4465-4469.

Barber DF, Bartolome A, Hernandez C, Flores JM, Fernandez-Arias C, Rodriguez-Borlado L, Hirsch E, Wymann M, Balomenos D, Carrera AC. 2006. Class IB-phosphatidylinositol 3-kinase (PI3K) deficiency ameliorates IA-PI3K-induced systemic lupus but not T cell invasion. J Immunol 176: 589-593.

Barouch-Bentov R, Altman A. 2006. Protein Kinase C-Theta (PKCtheta): New Perspectives on Its Functions in T-Cell Biology. In Advances in Experimental Medicine and Biology (ed. CD Tsoukas), pp. 1-14. Springer, New York, NY.

Betz A, Ashery U, Rickmann M, Augustin I, Neher E, Sudhof TC, Rettig J, Brose N. 1998. Munc13-1 is a presynaptic phorbol ester receptor that enhances neurotransmitter release. Neuron 21: 123-136.

Broussard C, Fleischacker C, Horai R, Chetana M, Venegas AM, Sharp LL, Hedrick SM, Fowlkes BJ, Schwartzberg PL. 2006. Altered development of $\mathrm{CD}^{+} \mathrm{T}$ cell lineages in mice deficient for the Tec kinases Itk and Rlk. Immunity 25: 93-104.

Buckler JL, Liu X, Turka LA. 2008. Regulation of T-cell responses by PTEN. Immunol Rev 224: 239-248.

Buitenhuis M, Coffer PJ. 2009. The role of the PI3K-PKB signaling module in regulation of hematopoiesis. Cell Cycle 8: 560-566.

Burton A, Hu X, Saiardi A. 2009. Are inositol pyrophosphates signalling molecules? J Cell Physiol 220: 8-15. 
Y.H. Huang and K. Sauer

Caffrey JJ, Darden T, Wenk MR, Shears SB. 2001. Expanding coincident signaling by PTEN through its inositol 1,3,4,5,6-pentakisphosphate 3-phosphatase activity. FEBS Lett 499: 6-10.

Calleja V, Alcor D, Laguerre M, Park J, Vojnovic B, Hemmings BA, Downward J, Parker PJ, Larijani B. 2007. Intramolecular and intermolecular interactions of protein kinase B define its activation in vivo. PLoS Biol 5: e95.

Caloca MJ, Delgado P, Alarcon B, Bustelo XR. 2008. Role of chimaerins, a group of Rac-specific GTPase activating proteins, in T-cell receptor signaling. Cell Signal 20: $758-770$.

Carrasco S, Merida I. 2004. Diacylglycerol-dependent binding recruits PKCtheta and RasGRP1 C1 domains to specific subcellular localizations in living $\mathrm{T}$ lymphocytes. Mol Biol Cell 15: 2932-2942.

Ceccarelli DF, Blasutig IM, Goudreault M, Li Z, Ruston J, Pawson T, Sicheri F. 2007. Non-canonical interaction of phosphoinositides with pleckstrin homology domains of Tiam1 and ArhGAP9. J Biol Chem 282: 13864-13874.

Chamberlain PP, Sandberg ML, Sauer K, Cooke MP, Lesley SA, Spraggon G. 2005. Structural insights into enzyme regulation for inositol 1,4,5-trisphosphate 3-kinase B. Biochem 44: 14486-14493.

Chen X, Priatel JJ, Chow MT, Teh HS. 2008. Preferential development of CD4 and CD8 T regulatory cells in RasGRP1-deficient mice. J Immunol 180: 5973-5982.

Ching KA, Kawakami Y, Kawakami T, Tsoukas CD. 1999. Emt/Itk associates with activated TCR complexes: role of the pleckstrin homology domain. J Immunol 163: 6006-6013.

Clayton E, Bardi G, Bell SE, Chantry D, Downes CP, Gray A, Humphries LA, Rawlings D, Reynolds H, Vigorito E, et al. 2002. A crucial role for the p110delta subunit of phosphatidylinositol 3-kinase in B cell development and activation. J Exp Med 196: 753-763.

Cozier G, Sessions R, Bottomley JR, Reynolds JS, Cullen PJ. 2000a. Molecular modelling and site-directed mutagenesis of the inositol 1,3,4,5-tetrakisphosphatebinding pleckstrin homology domain from the Ras GTPase-activating protein GAP1IP4BP. Biochem J 349: $333-342$.

Cozier GE, Carlton J, Bouyoucef D, Cullen PJ. 2004. Membrane targeting by pleckstrin homology domains. Curr Top Microbiol Immunol 282: 49-88.

Cozier GE, Lockyer PJ, Reynolds JS, Kupzig S, Bottomley JR, Millard TH, Banting G, Cullen PJ. 2000b. GAP1IP4BP contains a novel group I pleckstrin homology domain that directs constitutive plasma membrane association. J Biol Chem 275: 28261-28268.

Cremasco V, Benasciutti E, Cella M, Kisseleva M, Croke M, Faccio R. 2010. Phospholipase C gamma 2 is critical for development of a murine model of inflammatory arthritis by affecting actin dynamics in dendritic cells. PLoS One 5: e8909.

Cremasco V, Graham DB, Novack DV, Swat W, Faccio R. 2008. Vav/Phospholipase Cgamma2-mediated control of a neutrophil-dependent murine model of rheumatoid arthritis. Arthritis Rheum 58: 2712-2722.

Cullen PJ, Hsuan JJ, Truong O, Letcher AJ, Jackson TR, Dawson AP, Irvine RF. 1995. Identification of a specific
Ins $(1,3,4,5) \mathrm{P} 4$-binding protein as a member of the GAP1 family. Nature 376: 527-530.

Damen JE, Liu L, Rosten P, Humphries RK, Jefferson AB, Majerus PW, Krystal G. 1996. The 145-kDa protein induced to associate with Shc by multiple cytokines is an inositol tetraphosphate and phosphatidylinositol 3,4,5-triphosphate 5-phosphatase. Proc Natl Acad Sci U S A 93: 1689-1693.

Deane JA, Kharas MG, Oak JS, Stiles LN, Luo J, Moore TI, Ji H, Rommel C, Cantley LC, Lane TE, et al. 2007. T-cell function is partially maintained in the absence of class IA phosphoinositide 3-kinase signaling. Blood 109: 2894-2902.

Deane JA, Trifilo MJ, Yballe CM, Choi S, Lane TE, Fruman DA. 2004. Enhanced T cell proliferation in mice lacking the p85beta subunit of phosphoinositide 3-kinase. $J$ Immunol 172: 6615-6625.

Debnath J, Chamorro M, Czar MJ, Schaeffer EM, Lenardo MJ, Varmus HE, Schwartzberg PL. 1999. rlk/TXK encodes two forms of a novel cysteine string tyrosine kinase activated by Src family kinases. Mol Cell Biol 19: 1498-1507.

del Peso L, Gonzalez-Garcia M, Page C, Herrera R, Nunez G. 1997. Interleukin-3-induced phosphorylation of BAD through the protein kinase Akt. Science 278: 687-689.

Di Cristofano A, Kotsi P, Peng YF, Cordon-Cardo C, Elkon KB, Pandolfi PP. 1999. Impaired Fas response and autoimmunity in Pten ${ }^{+/}$mice. Science 285: 2122-2125.

Di Cristofano A, Pandolfi PP. 2000. The multiple roles of PTEN in tumor suppression. Cell 100: 387-390.

Di Cristofano A, Pesce B, Cordon-Cardo C, Pandolfi PP. 1998. Pten is essential for embryonic development and tumour suppression. Nat Genet 19: 348-355.

DiNitto JP, Lambright DG. 2006. Membrane and juxtamembrane targeting by PH and PTB domains. Biochim Biophys Acta 1761: 850-867.

Dombroski D, Houghtling RA, Labno CM, Precht P, Takesono A, Caplen NJ, Billadeau DD, Wange RL, Burkhardt JK, Schwartzberg PL. 2005. Kinase-independent functions for Itk in TCR-induced regulation of Vav and the actin cytoskeleton. J Immunol 174: 1385-1392.

Dower NA, Stang SL, Bottorff DA, Ebinu JO, Dickie P, Ostergaard HL, Stone JC. 2000. RasGRP is essential for mouse thymocyte differentiation and TCR signaling. Nat Immunol 1: 317-321.

Downing AK, Driscoll PC, Gout I, Salim K, Zvelebil MJ, Waterfield MD. 1994. Three-dimensional solution structure of the pleckstrin homology domain from dynamin. Curr Biol 4: 884-891.

Dufner A, Andjelkovic M, Burgering BM, Hemmings BA, Thomas G. 1999. Protein kinase B localization and activation differentially affect $\mathrm{S} 6$ kinase 1 activity and eukaryotic translation initiation factor 4 E-binding protein 1 phosphorylation. Mol Cell Biol 19: 4525-4534.

Epple H, Cremasco V, Zhang K, Mao D, Longmore GD, Faccio R. 2008. Phospholipase Cgamma2 modulates integrin signaling in the osteoclast by affecting the localization and activation of Src kinase. Mol Cell Biol 28: $3610-3622$.

Erneux C, Govaerts C, Communi D, Pesesse X. 1998. The diversity and possible functions of the inositol 
polyphosphate 5-phosphatases. Biochimica et Biophysica Acta (BBA) - Molecular and Cell Biology of Lipids 1436: 185-199.

Falasca M, Logan SK, Lehto VP, Baccante G, Lemmon MA, Schlessinger J. 1998. Activation of phospholipase C gamma by PI 3-kinase-induced PH domain-mediated membrane targeting. Embo J 17: 414-422.

Ferguson KM, Lemmon MA, Schlessinger J, Sigler PB. 1994. Crystal structure at $2.2 \mathrm{~A}$ resolution of the pleckstrin homology domain from human dynamin. Cell 79: 199-209.

Feske S. 2007. Calcium signalling in lymphocyte activation and disease. Nat Rev Immunol 7: 690-702.

Finkelstein LD, Shimizu Y, Schwartzberg PL. 2005. Tec kinases regulate TCR-mediated recruitment of signaling molecules and integrin-dependent cell adhesion. $J$ Immunol 175: 5923-5930.

Fowell DJ, Shinkai K, Liao XC, Beebe AM, Coffman RL, Littman DR, Locksley RM. 1999. Impaired NFATc translocation and failure of Th2 development in Itk-deficient $\mathrm{CD}^{+} \mathrm{T}$ cells. Immunity 11: 399-409.

Frauwirth KA, Riley JL, Harris MH, Parry RV, Rathmell JC, Plas DR, Elstrom RL, June CH, Thompson CB. 2002. The CD28 signaling pathway regulates glucose metabolism. Immunity 16: 769-777.

Frederick JP, Mattiske D, Wofford JA, Megosh LC, Drake LY, Chiou ST, Hogan BL, York JD. 2005. An essential role for an inositol polyphosphate multikinase, Ipk2, in mouse embryogenesis and second messenger production. Proc Natl Acad Sci U S A 102: 8454-8459.

Fruman DA, Bismuth G. 2009. Fine tuning the immune response with PI3K. Immunol Rev 228: 253-272.

Fruman DA, Mauvais-Jarvis F, Pollard DA, Yballe CM, Brazil D, Bronson RT, Kahn CR, Cantley LC. 2000. Hypoglycaemia, liver necrosis and perinatal death in mice lacking all isoforms of phosphoinositide 3-kinase p85 alpha. Nat Genet 26: 379-382.

Fu G, Chen Y, Yu M, Podd A, Schuman J, He Y, Di L, Yassai M, Haribhai D, North PE, et al. 2010. Phospholipase $\mathrm{C}\{$ gamma $\} 1$ is essential for $\mathrm{T}$ cell development, activation, and tolerance. J Exp Med 207: 309-318.

Gallo EM, Winslow MM, Cante-Barrett K, Radermacher AN, Ho L, McGinnis L, Iritani B, Neilson JR, Crabtree GR. 2007. Calcineurin sets the bandwidth for discrimination of signals during thymocyte development. Nature 450: 731-735.

Gao X, Harris TK. 2006. Role of the PH domain in regulating in vitro autophosphorylation events required for reconstitution of PDK1 catalytic activity. Bioorg Chem 34: $200-223$.

Gardai SJ, Hildeman DA, Frankel SK, Whitlock BB, Frasch SC, Borregaard N, Marrack P, Bratton DL, Henson PM. 2004. Phosphorylation of Bax Ser184 by Akt regulates its activity and apoptosis in neutrophils. $J$ Biol Chem 279: $21085-21095$.

Gomez-Rodriguez J, Readinger JA, Viorritto IC, Mueller KL, Houghtling RA, Schwartzberg PL. 2007. Tec kinases, actin, and cell adhesion. Immunol Rev 218: 45-64.

Graham DB, Robertson CM, Bautista J, Mascarenhas F, Diacovo MJ, Montgrain V, Lam SK, Cremasco V, Dunne WM, Faccio R, et al. 2007. Neutrophil-mediated oxidative burst and host defense are controlled by a Vav-PLCgamma2 signaling axis in mice. J Clin Invest 117: 3445-3452.

Grasis JA, Browne CD, Tsoukas CD. 2003. Inducible T cell tyrosine kinase regulates actin-dependent cytoskeletal events induced by the $\mathrm{T}$ cell antigen receptor. J Immunol 170: 3971-3976.

Guo R, Wan CK, Carpenter JH, Mousallem T, Boustany RM, Kuan CT, Burks AW, Zhong XP. 2008. Synergistic control of $\mathrm{T}$ cell development and tumor suppression by diacylglycerol kinase alpha and zeta. Proc Natl Acad Sci U S A 105: 11909-11914.

Hagenbeek TJ, Naspetti M, Malergue F, Garcon F, Nunes JA, Cleutjens KBJM, Trapman J, Krimpenfort P, Spits H. 2004. The Loss of PTEN Allows TCR \{alpha $\}$ beta $\}$ Lineage Thymocytes to Bypass IL-7 and Pre-TCR-mediated Signaling. J Exp Med 200: 883-894.

Han J, Luby-Phelps K, Das B, Shu X, Xia Y, Mosteller RD, Krishna UM, Falck JR, White MA, Broek D. 1998. Role of substrates and products of PI 3-kinase in regulating activation of Rac-related guanosine triphosphatases by Vav. Science 279: 558-560.

Harris SJ, Parry RV, Westwick J, Ward SG. 2008. Phosphoinositide lipid phosphatases: natural regulators of phosphoinositide 3-kinase signaling in T lymphocytes. J Biol Chem 283: 2465-2469.

Haslam RJ, Koide HB, Hemmings BA. 1993. Pleckstrin domain homology. Nature 363: 309-310.

Helgason CD, Damen JE, Rosten P, Grewal R, Sorensen P, Chappel SM, Borowski A, Jirik F, Krystal G, Humphries RK. 1998. Targeted disruption of SHIP leads to hemopoietic perturbations, lung pathology, and a shortened life span. Genes Dev 12: 1610-1620.

Hermosura MC, Takeuchi H, Fleig A, Riley AM, Potter BV, Hirata M, Penner R. 2000. InsP4 facilitates store-operated calcium influx by inhibition of InsP3 5-phosphatase. Nature 408: 735-740.

Heyeck SD, Wilcox HM, Bunnell SC, Berg LJ. 1997. Lck phosphorylates the activation loop tyrosine of the Itk kinase domain and activates Itk kinase activity. J Biol Chem 272: 25401-25408.

Hirata M, Kanematsu T, Takeuchi H, Yagisawa H. 1998. Pleckstrin homology domain as an inositol compound binding module. Jpn J Pharmacol 76: 255-263.

Horai R, Mueller KL, Handon RA, Cannons JL, Anderson SM, Kirby MR, Schwartzberg PL. 2007. Requirements for selection of conventional and innate T lymphocyte lineages. Immunity 27: 775-785.

Huang YH, Barouch-Bentov R, Herman A, Walker J, Sauer K. 2006. Integrating traditional and postgenomic approaches to investigate lymphocyte development and function. Adv Exp Med Biol 584: 245-276.

Huang YH, Grasis JA, Miller AT, Xu R, Soonthornvacharin S, Andreotti AH, Tsoukas CD, Cooke MP, Sauer K. 2007. Positive regulation of Itk PH domain function by soluble IP4. Science 316: 886-889.

Huang YH, Hoebe K, Sauer K. 2008. New therapeutic targets in immune disorders: ItpkB, Orail and UNC93B. Expert Opin Ther Targets 12: 391-413. 
Y.H. Huang and K. Sauer

Hubner A, Barrett T, Flavell RA, Davis RJ. 2008. Multisite phosphorylation regulates Bim stability and apoptotic activity. Mol Cell 30: 415-425.

Imboden JB, Pattison G. 1987. Regulation of inositol 1,4,5trisphosphate kinase activity after stimulation of human T cell antigen receptor. J Clin Invest 79: 1538-1541.

Irvine R. 2001. Inositol phosphates: Does IP(4) run a protection racket? Curr Biol 11: R172-174.

Irvine R. 2007. Cell signaling. The art of the soluble. Science 316: $845-846$.

Irvine RF. 2005. Inositide evolution - towards turtle domination? J Physiol 566: 295-300.

Irvine RF, Lloyd-Burton SM, Yu JC, Letcher AJ, Schell MJ. 2006. The regulation and function of inositol 1,4,5-trisphosphate 3-kinases. Adv Enzyme Regul 46: 314-323.

Irvine RF, Schell MJ. 2001. Back in the water: the return of the inositol phosphates. Nat Rev Mol Cell Biol 2: $327-338$.

Isakov N, Altman A. 2002. Protein kinase C(theta) in T cell activation. Annu Rev Immunol 20: 761-794.

Jacobs SR, Herman CE, Maciver NJ, Wofford JA, Wieman HL, Hammen JJ, Rathmell JC. 2008. Glucose uptake is limiting in $\mathrm{T}$ cell activation and requires CD28-mediated Akt-dependent and independent pathways. J Immunol 180: $4476-4486$.

James SR, Downes CP, Gigg R, Grove SJ, Holmes AB, Alessi DR. 1996. Specific binding of the Akt-1 protein kinase to phosphatidylinositol 3,4,5-trisphosphate without subsequent activation. Biochem J 315: 709-713.

Jarmin SJ, David R, Ma L, Chai JG, Dewchand H, Takesono A, Ridley AJ, Okkenhaug K, Marelli-Berg FM. 2008. T cell receptor-induced phosphoinositide-3-kinase p110delta activity is required for $\mathrm{T}$ cell localization to antigenic tissue in mice. J Clin Invest 118: 1154-1164.

Ji H, Rintelen F, Waltzinger C, Bertschy Meier D, Bilancio A, Pearce W, Hirsch E, Wymann MP, Ruckle T, Camps M, et al. 2007. Inactivation of PI3Kgamma and PI3Kdelta distorts T-cell development and causes multiple organ inflammation. Blood 110: 2940-2947.

Ji QS, Winnier GE, Niswender KD, Horstman D, Wisdom R, Magnuson MA, Carpenter G. 1997. Essential role of the tyrosine kinase substrate phospholipase C-gammal in mammalian growth and development. Proc Natl Acad Sci U S A 94: 2999-3003.

Jia Y, Loison F, Hattori H, Li Y, Erneux C, Park SY, Gao C, Chai L, Silberstein LE, Schurmans S, et al. 2008a. Inositol trisphosphate 3-kinase B (InsP3KB) as a physiological modulator of myelopoiesis. Proc Natl Acad Sci U S A 105: 4739-4744.

Jia Y, Schurmans S, Luo HR. 2008b. Regulation of innate immunity by inositol 1,3,4,5-tetrakisphosphate. Cell Cycle 7: 2803-2808.

Jia Y, Subramanian KK, Erneux C, Pouillon V, Hattori H, Jo H, You J, Zhu D, Schurmans S, Luo HR. 2007. Inositol 1,3,4,5-tetrakisphosphate negatively regulates phosphatidylinositol-3,4,5-trisphosphate signaling in neutrophils. Immunity 27: 453-467.

Joseph RE, Min L, Xu R, Musselman ED, Andreotti AH. 2007. A remote substrate docking mechanism for the tec family tyrosine kinases. Biochem 46: 5595-5603.
Jun K, Choi G, Yang SG, Choi KY, Kim H, Chan GC, Storm DR, Albert C, Mayr GW, Lee CJ, et al. 1998. Enhanced hippocampal CA1 LTP but normal spatial learning in inositol 1,4,5-trisphosphate 3-kinase(A)-deficient mice. Learn Mem 5: 317-330.

Juntilla MM, Koretzky GA. 2008. Critical roles of the PI3K/ Akt signaling pathway in T cell development. Immunol Lett 116: 104-110.

Juntilla MM, Wofford JA, Birnbaum MJ, Rathmell JC, Koretzky GA. 2007. Akt1 and Akt2 are required for alphabeta thymocyte survival and differentiation. Proc Natl Acad Sci U S A 104: 12105-12110.

Kavanaugh WM, Pot DA, Chin SM, Deuter-Reinhard M, Jefferson AB, Norris FA, Masiarz FR, Cousens LS, Majerus PW, Williams LT. 1996. Multiple forms of an inositol polyphosphate 5-phosphatase form signaling complexes with Shc and Grb2. Curr Biol 6: 438-445.

Kim IH, Park SK, Hong ST, Jo YS, Kim EJ, Park EH, Han SB, Shin HS, Sun W, Kim HT, et al. 2009. Inositol 1,4,5-trisphosphate 3-kinase a functions as a scaffold for synaptic Rac signaling. J Neurosci 29: 14039-14049.

Lemmon MA. 2008. Membrane recognition by phospholipid-binding domains. Nat Rev Mol Cell Biol 9: 99-111.

Liang J, Zubovitz J, Petrocelli T, Kotchetkov R, Connor MK, Han K, Lee JH, Ciarallo S, Catzavelos C, Beniston R, et al. 2002. PKB/Akt phosphorylates p27, impairs nuclear import of p27 and opposes p27-mediated G1 arrest. Nat Med 8: 1153-1160.

Liao XC, Littman DR. 1995. Altered T cell receptor signaling and disrupted $\mathrm{T}$ cell development in mice lacking Itk. Immunity 3: 757-769.

Lioubin MN, Algate PA, Tsai S, Carlberg K, Aebersold A, Rohrschneider LR. 1996. p150Ship, a signal transduction molecule with inositol polyphosphate-5-phosphatase activity. Genes Dev 10: 1084-1095.

Liu D, Uzonna JE. 2010. The p110\{delta\} Isoform of Phosphatidylinositol 3-Kinase Controls the Quality of Secondary Anti-Leishmania Immunity by Regulating Expansion and Effector Function of Memory T Cell Subsets. J Immunol 184: 3098-3105.

Liu D, Zhang T, Marshall AJ, Okkenhaug K, Vanhaesebroeck B, Uzonna JE. 2009a. The p110delta isoform of phosphatidylinositol 3-kinase controls susceptibility to Leishmania major by regulating expansion and tissue homing of regulatory T cells. J Immunol 183: 1921-1933.

Liu KQ, Bunnell SC, Gurniak CB, Berg LJ. 1998. T cell receptor-initiated calcium release is uncoupled from capacitative calcium entry in Itk-deficient T cells. J Exp Med 187: 1721-1727.

Liu P, Cheng H, Roberts TM, Zhao JJ. 2009b. Targeting the phosphoinositide 3-kinase pathway in cancer. Nat Rev Drug Discov 8: 627-644.

Lockyer PJ, Bottomley JR, Reynolds JS, McNulty TJ, Venkateswarlu K, Potter BV, Dempsey CE, Cullen PJ. 1997. Distinct subcellular localisations of the putative inositol 1,3,4,5-tetrakisphosphate receptors GAPIIP4BP and GAP1m result from the GAP1IP4BP PH domain directing plasma membrane targeting. Curr Biol 7: 1007-1010.

Lucas JA, Felices M, Evans JW, Berg LJ. 2007. Subtle defects in pre-TCR signaling in the absence of the Tec kinase Itk. $J$ Immunol 179: 7561-7567. 
Lipid Signaling in T-cell Development and Function

Macian F, Garcia-Cozar F, Im SH, Horton HF, Byrne MC, Rao A. 2002. Transcriptional mechanisms underlying lymphocyte tolerance. Cell 109: 719-731.

Macias MJ, Musacchio A, Ponstingl H, Nilges M, Saraste M, Oschkinat H. 1994. Structure of the pleckstrin homology domain from beta-spectrin. Nature 369: 675-677.

Madrid LV, Wang CY, Guttridge DC, Schottelius AJ, Baldwin AS Jr, Mayo MW. 2000. Akt suppresses apoptosis by stimulating the transactivation potential of the RelA/p65 subunit of NF-kappaB. Mol Cell Biol 20: 1626-1638.

Maehama T, Dixon JE. 1998. The tumor suppressor, PTEN/ MMAC1, dephosphorylates the lipid second messenger, phosphatidylinositol 3,4,5-trisphosphate. J Biol Chem 273: $13375-13378$.

Manicassamy S, Gupta S, Sun Z. 2006. Selective function of PKC-theta in T cells. Cell Mol Immunol 3: 263-270.

Manning BD, Cantley LC. 2007. AKT/PKB signaling: navigating downstream. Cell 129: 1261-1274.

Marechal Y, Pesesse X, Jia Y, Pouillon V, Perez-Morga D, Daniel J, Izui S, Cullen PJ, Leo O, Luo HR, et al. 2007. Inositol 1,3,4,5-tetrakisphosphate controls proapoptotic Bim gene expression and survival in B cells. Proc Natl Acad Sci U S A 104: 13978-13983.

Martin AL, Schwartz MD, Jameson SC, Shimizu Y. 2008. Selective regulation of CD8 effector $\mathrm{T}$ cell migration by the p110 gamma isoform of phosphatidylinositol 3-kinase. J Immunol 180: 2081-2088.

Matheu MP, Deane JA, Parker I, Fruman DA, Cahalan MD. 2007. Class IA phosphoinositide 3-kinase modulates basal lymphocyte motility in the lymph node. J Immunol 179: $2261-2269$.

Mayer BJ, Ren R, Clark KL, Baltimore D. 1993. A putative modular domain present in diverse signaling proteins. Cell 73: 629-630.

McGargill MA, Ch'en IL, Katayama CD, Pages G, Pouyssegur J, Hedrick SM. 2009. Cutting Edge: Extracellular Signal-Related Kinase Is Not Required for Negative Selection of Developing T Cells. J Immunol 183: 4838-4842.

McLaughlin S, Wang J, Gambhir A, Murray D. 2002. PIP(2) and proteins: interactions, organization, and information flow. Annu Rev Biophys Biomol Struct 31: 151-175.

Michell RH, Heath VL, Lemmon MA, Dove SK. 2006. Phosphatidylinositol 3,5-bisphosphate: metabolism and cellular functions. Trends Biochem Sci 31: 52-63.

Miller AT, Beisner DR, Liu D, Cooke MP. 2009. Inositol 1,4,5-trisphosphate 3-kinase $\mathrm{B}$ is a negative regulator of $\mathrm{BCR}$ signaling that controls $\mathrm{B}$ cell selection and tolerance induction. J Immunol 182: 4696-4704.

Miller AT, Chamberlain PP, Cooke MP. 2008. Beyond IP3: roles for higher order inositol phosphates in immune cell signaling. Cell Cycle 7: 463-467.

Miller AT, Sandberg M, Huang YH, Young M, Sutton S, Sauer K, Cooke MP. 2007a. Production of Ins $(1,3,4,5) \mathrm{P} 4$ mediated by the kinase Itpkb inhibits store-operated calcium channels and regulates B cell selection and activation. Nat Immunol 8: 514-521.

Miller AT, Sandberg M, Huang YH, Young M, Sutton S, Sauer K, Cooke MP. 2007b. Production of Ins $(1,3,4,5) \mathrm{P}(4)$ mediated by the kinase Itpkb inhibits store-operated calcium channels and regulates $B$ cell selection and activation. Nat Immunol 8: 514-521.
Min L, Joseph RE, Fulton DB, Andreotti AH. 2009. Itk tyrosine kinase substrate docking is mediated by a nonclassical SH2 domain surface of PLCgammal. Proc Natl Acad Sci U S A 106: 21143-21148.

Morley SC, Weber KS, Kao H, Allen PM. 2008. Protein kinase C-theta is required for efficient positive selection. $J$ Immunol 181: 4696-4708.

Nalaskowski MM, Mayr GW. 2004. The families of kinases removing the $\mathrm{Ca}^{2+}$ releasing second messenger Ins(1,4,5)P3. Curr Mol Med 4: 277-290.

Nashed BF, Zhang T, Al-Alwan M, Srinivasan G, Halayko AJ, Okkenhaug K, Vanhaesebroeck B, Hayglass KT, Marshall AJ. 2007. Role of the phosphoinositide 3-kinase p110delta in generation of type 2 cytokine responses and allergic airway inflammation. Eur J Immunol 37: $416-424$.

Neilson JR, Winslow MM, Hur EM, Crabtree GR. 2004. Calcineurin B1 is essential for positive but not negative selection during thymocyte development. Immunity 20: $255-266$.

Niki I, Yokokura H, Sudo T, Kato M, Hidaka H. 1996. Ca2+ signaling and intracellular Ca2+ binding proteins. J Biochem 120: 685-698.

Oak JS, Deane JA, Kharas MG, Luo J, Lane TE, Cantley LC, Fruman DA. 2006. Sjogren's syndrome-like disease in mice with $\mathrm{T}$ cells lacking class $1 \mathrm{~A}$ phosphoinositide-3kinase. Proc Natl Acad Sci U S A 103: 16882-16887.

Oh-hora M, Rao A. 2008. Calcium signaling in lymphocytes. Curr Opin Immunol 20: 250-258.

Okkenhaug K, Bilancio A, Farjot G, Priddle H, Sancho S, Peskett E, Pearce W, Meek SE, Salpekar A, Waterfield $\mathrm{MD}$, et al. 2002. Impaired B and T cell antigen receptor signaling in p110delta PI 3-kinase mutant mice. Science 297: $1031-1034$.

Okkenhaug K, Patton DT, Bilancio A, Garcon F, Rowan WC, Vanhaesebroeck B. 2006. The p110delta isoform of phosphoinositide 3-kinase controls clonal expansion and differentiation of Th cells. J Immunol 177: 5122-5128.

Olenchock BA, Guo R, Carpenter JH, Jordan M, Topham MK, Koretzky GA, Zhong XP. 2006. Disruption of diacylglycerol metabolism impairs the induction of $\mathrm{T}$ cell anergy. Nat Immunol 7: 1174-1181.

Onouchi Y, Gunji T, Burns JC, Shimizu C, Newburger JW, Yashiro M, Nakamura Y, Yanagawa H, Wakui K, Fukushima Y, et al. 2008. ITPKC functional polymorphism associated with Kawasaki disease susceptibility and formation of coronary artery aneurysms. Nat Genet 40: 35-42.

Otto JC, Mulugu S, Fridy PC, Chiou ST, Armbruster BN, Ribeiro AA, York JD. 2007. Biochemical analysis of inositol phosphate kinases. Methods Enzymol 434: 171-185.

Outram SV, Crompton T, Merida I, Varas A, Martinez AC. 2002. Diacylglycerol kinase alpha activity promotes survival of $\mathrm{CD} 4^{+} 8^{+}$double positive cells during thymocyte development. Immunology 105: 391-398.

Panka DJ, Mano T, Suhara T, Walsh K, Mier JW. 2001. Phosphatidylinositol 3-kinase/Akt activity regulates c-FLIP expression in tumor cells. J Biol Chem 276: 6893-6896.

Pattni K, Banting G. 2004. Ins(1,4,5)P3 metabolism and the family of IP3-3Kinases. Cell Signal 16: 643-654.

Patton DT, Garden OA, Pearce WP, Clough LE, Monk CR, Leung E, Rowan WC, Sancho S, Walker LS, 
Y.H. Huang and K. Sauer

Vanhaesebroeck B, et al. 2006. Cutting edge: the phosphoinositide 3-kinase p110 delta is critical for the function of $\mathrm{CD}^{+} \mathrm{CD}^{+} 5^{+} \mathrm{Foxp}^{+}$regulatory T cells. $J$ Immunol 177: 6598-6602.

Pesesse X, Moreau C, Drayer AL, Woscholski R, Parker P, Erneux C. 1998. The SH2 domain containing inositol 5-phosphatase SHIP2 displays phosphatidylinositol 3,4,5-trisphosphate and inositol 1,3,4,5-tetrakisphosphate 5-phosphatase activity. FEBS Lett 437: 301-303.

Pouillon V, Hascakova-Bartova R, Pajak B, Adam E, Bex F, Dewaste V, Van Lint C, Leo O, Erneux C, Schurmans S. 2003. Inositol 1,3,4,5-tetrakisphosphate is essential for T lymphocyte development. Nat Immunol 4: 1136-1143.

Priatel JJ, Chen X, Dhanji S, Abraham N, Teh HS. 2006. RasGRP1 transmits prodifferentiation TCR signaling that is crucial for $\mathrm{CD} 4 \mathrm{~T}$ cell development. J Immunol 177: $1470-1480$.

Priatel JJ, Chen X, Zenewicz LA, Shen H, Harder KW, Horwitz MS, Teh HS. 2007. Chronic immunodeficiency in mice lacking RasGRP1 results in CD4 T cell immune activation and exhaustion. J Immunol 179: 2143-2152.

Priatel JJ, Teh SJ, Dower NA, Stone JC, Teh HS. 2002. RasGRP1 transduces low-grade TCR signals which are critical for T cell development, homeostasis, and differentiation. Immunity 17: 617-627.

Qi Q, August A. 2007. Keeping the (kinase) party going: SLP-76 and ITK dance to the beat. Sci STKE 2007: e39.

Qi XJ, Wildey GM, Howe PH. 2006. Evidence that Ser87 of BimEL is phosphorylated by Akt and regulates BimEL apoptotic function. J Biol Chem 281: 813-823.

Rathmell JC, Elstrom RL, Cinalli RM, Thompson CB. 2003. Activated Akt promotes increased resting $\mathrm{T}$ cell size, CD28-independent $\mathrm{T}$ cell growth, and development of autoimmunity and lymphoma. Eur J Immunol 33: $2223-2232$.

Readinger JA, Mueller KL, Venegas AM, Horai R, Schwartzberg PL. 2009. Tec kinases regulate T-lymphocyte development and function: new insights into the roles of Itk and Rlk/Txk. Immunol Rev 228: 93-114.

Resnick AC, Saiardi A. 2008. Inositol polyphosphate multikinase: metabolic architect of nuclear inositides. Front Biosci 13: 856-866.

Rodriguez-Borlado L, Barber DF, Hernandez C, RodriguezMarcos MA, Sanchez A, Hirsch E, Wymann M, Martinez AC, Carrera AC. 2003. Phosphatidylinositol 3-kinase regulates the $\mathrm{CD} 4 / \mathrm{CD} 8 \mathrm{~T}$ cell differentiation ratio. J Immunol 170: 4475-4482.

Rosse C, Linch M, Kermorgant S, Cameron AJ, Boeckeler K, Parker PJ. 2010. PKC and the control of localized signal dynamics. Nat Rev Mol Cell Biol 11: 103-112.

Sasaki T, Irie-Sasaki J, Jones RG, Oliveira-dos-Santos AJ, Stanford WL, Bolon B, Wakeham A, Itie A, Bouchard D, Kozieradzki I, et al. 2000. Function of PI3Kgamma in thymocyte development, T cell activation, and neutrophil migration. Science 287: 1040-1046.

Sauer K, Cooke MP. 2010. Regulation of immune cell development through soluble inositol $(1,3,4,5)$ tetrakisphosphate. Nat Rev Immunol 10, 257-271.

Sauer K, Huang YH, Ying H, Sandberg M, Mayr GW. 2009. Phosphoinositide Analysis in Lymphocyte Activation. Curr Protoc Immunol 87: 11.11.11-11.11.46.
Schaeffer EM, Broussard C, Debnath J, Anderson S, McVicar DW, Schwartzberg PL. 2000. Tec family kinases modulate thresholds for thymocyte development and selection. J Exp Med 192: 987-1000.

Schaeffer EM, Debnath J, Yap G, McVicar D, Liao XC, Littman DR, Sher A, Varmus HE, Lenardo MJ, Schwartzberg PL. 1999. Requirement for Tec kinases Rlk and Itk in T cell receptor signaling and immunity. Science 284: 638-641.

Schaeffer EM, Yap GS, Lewis CM, Czar MJ, McVicar DW, Cheever AW, Sher A, Schwartzberg PL. 2001. Mutation of Tec family kinases alters $\mathrm{T}$ helper cell differentiation. Nat Immunol 2: 1183-1188.

Schell MJ. 2010. Inositol trisphosphate 3-kinases: focus on immune and neuronal signaling. Cell Mol Life Sci 67: $1755-1778$.

Shan X, Czar MJ, Bunnell SC, Liu P, Liu Y, Schwartzberg PL, Wange RL. 2000. Deficiency of PTEN in Jurkat T cells causes constitutive localization of Itk to the plasma membrane and hyperresponsiveness to $\mathrm{CD} 3$ stimulation. $\mathrm{Mol}$ Cell Biol 20: 6945-6957.

Shears SB. 2009. Molecular basis for the integration of inositol phosphate signaling pathways via human ITPK1. Adv Enzyme Regul 49: 87-96.

Shin I, Yakes FM, Rojo F, Shin NY, Bakin AV, Baselga J, Arteaga CL. 2002. PKB/Akt mediates cell-cycle progression by phosphorylation of p27(Kip1) at threonine 157 and modulation of its cellular localization. Nat Med 8: $1145-1152$.

Shirane M, Sawa H, Kobayashi Y, Nakano T, Kitajima K, Shinkai Y, Nagashima K, Negishi I. 2001. Deficiency of phospholipase C-gammal impairs renal development and hematopoiesis. Development 128: 5173-5180.

Shiroki F, Matsuda S, Doi T, Fujiwara M, Mochizuki Y, Kadowaki T, Suzuki H, Koyasu S. 2007. The p85alpha regulatory subunit of class IA phosphoinositide 3-kinase regulates beta-selection in thymocyte development. $J$ Immunol 178: 1349-1356.

Siliceo M, Garcia-Bernal D, Carrasco S, Diaz-Flores E, Coluccio Leskow F, Teixido J, Kazanietz MG, Merida I. 2006. Beta2-chimaerin provides a diacylglycerol-dependent mechanism for regulation of adhesion and chemotaxis of T cells. J Cell Sci 119: 141-152.

Siliceo M, Merida I. 2009. T cell receptor-dependent tyrosine phosphorylation of beta2-chimaerin modulates its Rac-GAP function in T cells. J Biol Chem 284: 11354-11363.

Sommers CL, Lee J, Steiner KL, Gurson JM, Depersis CL, El-Khoury D, Fuller CL, Shores EW, Love PE, Samelson LE. 2005. Mutation of the phospholipase C-gamma1binding site of LAT affects both positive and negative thymocyte selection. J Exp Med 201: 1125-1134.

Sommers CL, Park CS, Lee J, Feng C, Fuller CL, Grinberg A, Hildebrand JA, Lacana E, Menon RK, Shores EW, et al. 2002. A LAT mutation that inhibits T cell development yet induces lymphoproliferation. Science 296: $2040-$ 2043.

Soond DR, Bjorgo E, Moltu K, Dale VQ, Patton DT, Torgersen KM, Galleway F, Twomey B, Clark J, Gaston JH, et al. 2010. PI3K p110\{delta\} regulates T cell cytokine production during primary and secondary immune responses in mice and humans. Blood 115: 2203-2213. 
Lipid Signaling in T-cell Development and Function

Spitaler M, Emslie E, Wood CD, Cantrell D. 2006. Diacylglycerol and protein kinase $\mathrm{D}$ localization during $\mathrm{T}$ lymphocyte activation. Immunity 24: 535-546.

Starr TK, Jameson SC, Hogquist KA. 2003. Positive and negative selection of T cells. Annu Rev Immunol 21: 139-176.

Stephens L, Anderson K, Stokoe D, Erdjument-Bromage H, Painter GF, Holmes AB, Gaffney PR, Reese CB, McCormick F, Tempst P, et al. 1998. Protein kinase B kinases that mediate phosphatidylinositol 3,4,5-trisphosphatedependent activation of protein kinase B. Science 279: $710-714$.

Stephens L, Smrcka A, Cooke FT, Jackson TR, Sternweis PC, Hawkins PT. 1994. A novel phosphoinositide 3 kinase activity in myeloid-derived cells is activated by $\mathrm{G}$ protein beta gamma subunits. Cell 77: 83-93.

Stephens LR, Eguinoa A, Erdjument-Bromage H, Lui M, Cooke F, Coadwell J, Smrcka AS, Thelen M, Cadwallader $\mathrm{K}$, Tempst P, et al. 1997. The G beta gamma sensitivity of a PI3K is dependent upon a tightly associated adaptor, p101. Cell 89: 105-114.

Stokoe D, Stephens LR, Copeland T, Gaffney PR, Reese CB, Painter GF, Holmes AB, McCormick F, Hawkins PT. 1997. Dual role of phosphatidylinositol-3,4,5trisphosphate in the activation of protein kinase B. Science 277: 567-570.

Stoyanov B, Volinia S, Hanck T, Rubio I, Loubtchenkov M, Malek D, Stoyanova S, Vanhaesebroeck B, Dhand R, Nurnberg B, et al. 1995. Cloning and characterization of a $G$ protein-activated human phosphoinositide-3 kinase. Science 269: 690-693.

Su YW, Zhang Y, Schweikert J, Koretzky GA, Reth M, Wienands J. 1999. Interaction of SLP adaptors with the $\mathrm{SH} 2$ domain of Tec family kinases. Eur J Immunol 29: 3702-3711.

Suire S, Coadwell J, Ferguson GJ, Davidson K, Hawkins P, Stephens L. 2005. p84, a new Gbetagamma-activated regulatory subunit of the type IB phosphoinositide 3-kinase p110gamma. Curr Biol 15: 566-570.

Suzuki A, Yamaguchi MT, Ohteki T, Sasaki T, Kaisho T, Kimura Y, Yoshida R, Wakeham A, Higuchi T, Fukumoto M, et al. 2001. T cell-specific loss of Pten leads to defects in central and peripheral tolerance. Immunity 14: $523-534$.

Swat W, Montgrain V, Doggett TA, Douangpanya J, Puri K, Vermi W, Diacovo TG. 2006. Essential role of PI3Kdelta and PI3Kgamma in thymocyte survival. Blood 107: 2415-2422.

Tarasenko T, Kole HK, Chi AW, Mentink-Kane MM, Wynn TA, Bolland S. 2007. T cell-specific deletion of the inositol phosphatase SHIP reveals its role in regulating Th1/Th2 and cytotoxic responses. Proc Natl Acad Sci U S A 104: 11382-11387.

Taylor CW, Rahman T, Tovey SC, Dedos SG, Taylor EJ, Velamakanni S. 2009. IP3 receptors: some lessons from DT40 cells. Immunol Rev 231: 23-44.

Thomas MS, Mitchell JS, DeNucci CC, Martin AL, Shimizu Y. 2008. The p110gamma isoform of phosphatidylinositol 3-kinase regulates migration of effector CD4 T lymphocytes into peripheral inflammatory sites. J Leukoc Biol 84: 814-823.

Timm D, Salim K, Gout I, Guruprasad L, Waterfield M, Blundell T. 1994. Crystal structure of the pleckstrin homology domain from dynamin. Nat Struct Biol 1: $782-788$.

Tomlinson MG, Kane LP, Su J, Kadlecek TA, Mollenauer MN, Weiss A. 2004. Expression and function of Tec, Itk, and Btk in lymphocytes: evidence for a unique role for Tec. Mol Cell Biol 24: 2455-2466.

van Rossum DB, Patterson RL, Sharma S, Barrow RK, Kornberg M, Gill DL, Snyder SH. 2005. Phospholipase Cgammal controls surface expression of TRPC 3 through an intermolecular PH domain. Nature 434: 99- 104.

Vanhaesebroeck B, Ali K, Bilancio A, Geering B, Foukas LC. 2005. Signalling by PI3K isoforms: insights from genetargeted mice. Trends Biochem Sci 30: 194-204.

Vanweyenberg V, Communi D, D'Santos CS, Erneux C. 1995. Tissue- and cell-specific expression of Ins (1,4,5)P3 3-kinase isoenzymes. Biochem J 306: 429-435.

Vig M, Kinet JP. 2009. Calcium signaling in immune cells. Nat Immunol 10: 21-27.

Viglietto G, Motti ML, Bruni P, Melillo RM, D’Alessio A, Califano D, Vinci F, Chiappetta G, Tsichlis P, Bellacosa A, et al. 2002. Cytoplasmic relocalization and inhibition of the cyclin-dependent kinase inhibitor p27(Kip1) by $\mathrm{PKB} /$ Akt-mediated phosphorylation in breast cancer. Nat Med 8: 1136-1144.

Wang CY, Mayo MW, Korneluk RG, Goeddel DV, Baldwin ASJr. 1998. NF-kappaB antiapoptosis: induction of TRAF1 and TRAF2 and c-IAP1 and c-IAP2 to suppress caspase-8 activation. Science 281: 1680-1683.

Wang D, Feng J, Wen R, Marine JC, Sangster MY, Parganas E, Hoffmeyer A, Jackson CW, Cleveland JL, Murray PJ, et al. 2000. Phospholipase Cgamma2 is essential in the functions of B cell and several Fc receptors. Immunity 13: $25-35$.

Wang X, Devaiah SP, Zhang W, Welti R. 2006. Signaling functions of phosphatidic acid. Prog Lipid Res 45: $250-278$.

Wange RL. 2000. LAT, the linker for activation of T cells: a bridge between $\mathrm{T}$ cell-specific and general signaling pathways. Sci STKE 2000: re1.

Webb LM, Vigorito E, Wymann MP, Hirsch E, Turner M. 2005. Cutting edge: T cell development requires the combined activities of the p110gamma and p110delta catalytic isoforms of phosphatidylinositol 3-kinase. J Immunol 175: 2783-2787.

Wen BG, Pletcher MT, Warashina M, Choe SH, Ziaee N, Wiltshire T, Sauer K, Cooke MP. 2004. Inositol $(1,4,5)$ trisphosphate 3 kinase $\mathrm{B}$ controls positive selection of $\mathrm{T}$ cells and modulates Erk activity. Proc Natl Acad Sci U S A 101: 5604-5609.

Wilde JI, Watson SP. 2001. Regulation of phospholipase C gamma isoforms in haematopoietic cells: why one, not the other? Cell Signal 13: 691-701.

Yang C, Kazanietz MG. 2007. Chimaerins: GAPs that bridge diacylglycerol signalling and the small G-protein Rac. Biochem J 403: 1-12.

Yoon HS, Hajduk PJ, Petros AM, Olejniczak ET, Meadows RP, Fesik SW. 1994. Solution structure of a pleckstrinhomology domain. Nature 369: 672-675.

York JD. 2006. Regulation of nuclear processes by inositol polyphosphates. Biochim Biophys Acta 1761: 552-559. 
Y.H. Huang and K. Sauer

York JD, Hunter T. 2004. Signal transduction. Unexpected mediators of protein phosphorylation. Science 306: 2053-2055.

Zha Y, Marks R, Ho AW, Peterson AC, Janardhan S, Brown I, Praveen K, Stang S, Stone JC, Gajewski TF. 2006. T cell anergy is reversed by active Ras and is regulated by diacylglycerol kinase-alpha. Nat Immunol 7: 1166-1173.
Zhong XP, Guo R, Zhou H, Liu C, Wan CK. 2008. Diacylglycerol kinases in immune cell function and self-tolerance. Immunol Rev 224: 249-264.

Zhong XP, Hainey EA, Olenchock BA, Jordan MS, Maltzman JS, Nichols KE, Shen H, Koretzky GA. 2003. Enhanced T cell responses due to diacylglycerol kinase zeta deficiency. Nat Immunol 4: 882-890. 


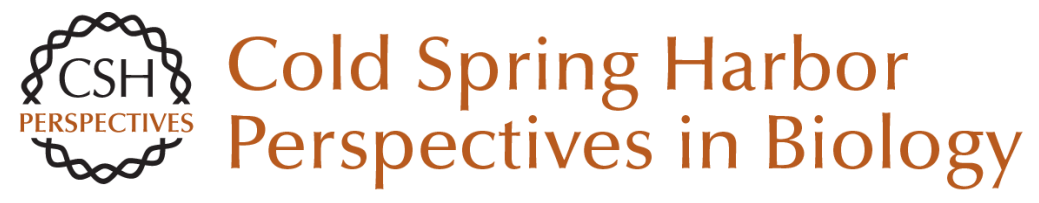

\section{Lipid Signaling in T-Cell Development and Function}

Yina H. Huang and Karsten Sauer

Cold Spring Harb Perspect Biol 2010; doi: 10.1101/cshperspect.a002428 originally published online October 13, 2010

\section{Subject Collection Immunoreceptor Signaling}

The Coordination of T-cell Function by Serine/Threonine Kinases

David Finlay and Doreen Cantrell

ITAM-mediated Signaling by the T-Cell Antigen Receptor

Paul E. Love and Sandra M. Hayes

Coordination of Receptor Signaling in Multiple Hematopoietic Cell Lineages by the Adaptor

Protein SLP-76

Martha S. Jordan and Gary A. Koretzky

The Cytoskeleton Coordinates the Early Events of B-cell Activation

Naomi E. Harwood and Facundo D. Batista

An Enigmatic Tail of CD28 Signaling

Jonathan S. Boomer and Jonathan M. Green

\section{Mediation of T-Cell Activation by Actin Meshworks \\ Peter Beemiller and Matthew F. Krummel}

T-Cell Signaling Regulated by the Tec Family

Kinase, Itk

Amy H. Andreotti, Pamela L. Schwartzberg, Raji E. Joseph, et al.
Perspectives for Computer Modeling in the Study of $\mathrm{T}$ Cell Activation Jesse Coward, Ronald N. Germain and Grégoire Altan-Bonnet

Structural Biology of the T-cell Receptor: Insights into Receptor Assembly, Ligand Recognition, and Initiation of Signaling

Kai W. Wucherpfennig, Etienne Gagnon, Melissa J. Call, et al.

Src-family and Syk Kinases in Activating and

Inhibitory Pathways in Innate Immune Cells:

Signaling Cross Talk Clifford A. Lowell

The LAT Story: A Tale of Cooperativity, Coordination, and Choreography

Lakshmi Balagopalan, Nathan P. Coussens, Eilon Sherman, et al.

Antigen Receptor Signaling to NF- $\mathrm{kB}$ via CARMA1, BCL10, and MALT1 Margot Thome, Jean Enno Charton, Christiane Pelzer, et al.

It's All About Change: The Antigen-driven Initiation of B-Cell Receptor Signaling Wanli Liu, Hae Won Sohn, Pavel Tolar, et al.

ZAP-70: An Essential Kinase in T-cell Signaling Haopeng Wang, Theresa A. Kadlecek, Byron B. Au-Yeung, et al.

For additional articles in this collection, see http://cshperspectives.cshlp.org/cgi/collection/

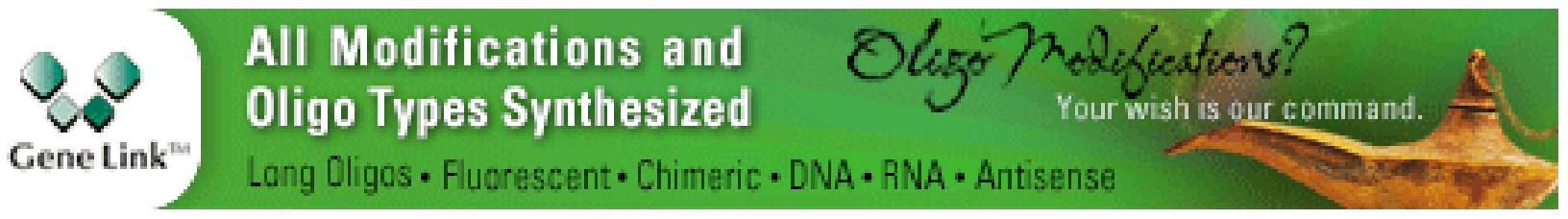




\section{Lipid Signaling in T-Cell Development and Function \\ Yina H. Huang and Karsten Sauer}

Understanding the Structure and Function of the Immunological Synapse

Michael L. Dustin, Arup K. Chakraborty and Andrey S. Shaw

For additional articles in this collection, see http://cshperspectives.cshlp.org/cgi/collection/

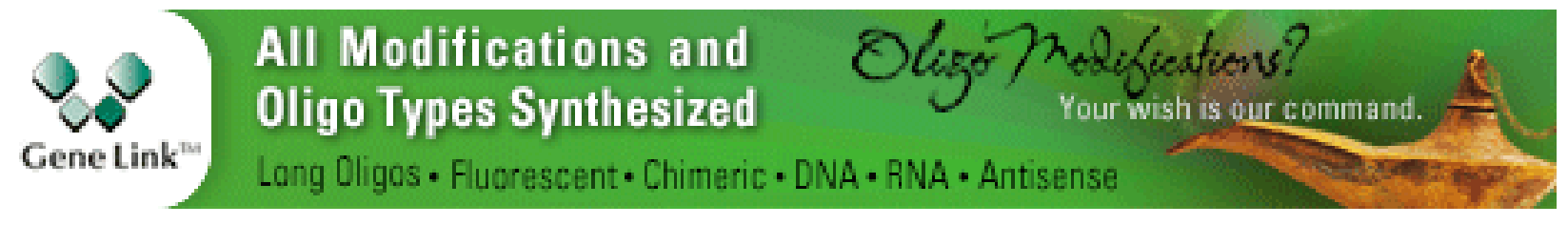

Copyright @ 2010 Cold Spring Harbor Laboratory Press; all rights reserved 